\author{
MAGDALENA BINIAŚ-SZKOPEK \\ https://orcid.org/0000-0003-2395-0896 \\ Instytut Historii \\ Uniwersytet im. A. Mickiewicza w Poznaniu
}

\title{
MAŁŻEŃSKA PRZESZKODA IMPOTENCJI I OZIĘBŁOŚCI PŁCIOWEJ W ŚWIETLE AKT POZNAŃSKIEGO KONSYSTORZA Z XV WIEKU
}

\begin{abstract}
Abstrakt: Małżeństwo od wieków stanowiło podstawę budowania społeczeństw, a jego zadaniem było spłodzenie i przygotowanie do życia kolejnego pokolenia. W takim rozumieniu impotencja traktowana była jako poważny problem uniemożliwiający inicjację związku. Księgi konsystorskie z terenu diecezji poznańskiej z lat 1404-1425 zawierają 22 przypadki spraw małżeństw, w których wystąpił problem impotencji. $\mathrm{Na}$ ich podstawie autorka odpowiada na pytania dotyczące przyczyn pojawienia się i sposobów rozwiązywania podobnych kwestii przez sądy kościelne.
\end{abstract}

Słowa kluczowe: małżeństwo, impotencja, oziębłość płciowa, konsystorz (oficjalat), sąd kościelny, czary.
Abstract: For centuries, marriage was the bedrock of societies, and its purpose was to beget children and prepare them for the future life. In such context, impotence was regarded as an important lack of physical capacity for consummation of the marital union. The consistorial records of the Poznan Diocese from the years 140425 include 22 instances of the marriages with the problem of impotence. On their basis the author answers the questions about their origins and solutions of similar matters proposed by the ecclesiastical courts.

Keywords: Marriage, impotence, frigidity, consistory (Church official's office), ecclesiastical court, witchcraft.

Małżeństwo od wieków stanowiło podstawę budowania rodziny oraz fundament więzi i rozwoju społecznego, a jego najważniejszym zadaniem było spłodzenie i przygotowanie do życia kolejnego pokolenia. Niezwykle istotnym elementem zawiązania więzi małżeńskiej już od starożytności była nie tylko ustna umowa (niekoniecznie wyrażona i zawiązana 
bezpośrednio przez parę), ale też dopełnienie następnie zawartych zobowiązań podjęciem współżycia. Oba elementy od początku odgrywały ważną, choć, jak zobaczymy poniżej, czasem dyskusyjną rolę w zakresie legitymizacji związku. Celem niniejszego tekstu jest przedstawienie wyników kwerendy dotyczącej małżeństw średniowiecznych z terenu diecezji poznańskiej, które stanęły wobec niemożności fizycznego dopełnienia małżeństwa - czyli problemu oziębłości i impotencji. Analiza zagadnienia została przeprowadzona na mało znanym i wybiórczo wykorzystywanym przez historyków materiale źródłowym - księgach z zapisami spraw pozostawionych przez sąd oficjała poznańskiego (Acta causarum, sygn. AC) przechowywanych w Archiwum Archidiecezjalnym w Poznaniu (dalej: AAP).

Od czasów wczesnego średniowiecza ludzie znali i stosowali różne wybiegi, by zabezpieczyć parę przed sytuacją, w której z jakichś powodów niemożliwe było podjęcie przez nią współżycia cielesnego. Niespełnione małżeństwo stanowiło realny problem zarówno rodzinny, jak i w dalszym wymiarze społeczny, w związku z czym należało się przed takim zagrożeniem jak najlepiej zabezpieczyć, a jeśli już problem wystąpił, próbowano go szybko rozwiązać. Nakłanianie partnera, by poszedł do klasztoru, ewentualnie małżonki do cichej ucieczki czy nawet poszukiwanie źródeł problemu przez podejmowanie współżycia poza związkiem były sposobami, jakie wykorzystywano w praktyce społecznej, na które jednak nie godził się Kościół ${ }^{1}$. Doskonałym przykładem był rytuał pokładzin, pilnie przestrzegany w ludowym obyczaju zaślubin jeszcze w XIX w., który nie tyle służył, jak zauważył Ludwik Stomma, potwierdzeniu dziewictwa panny młodej, ile ostatecznemu przypieczętowaniu związku oraz sprawdzeniu, czy nupturienci są w stanie również na tym polu rozpocząć wspólne życie ${ }^{2}$. Od XII w. kontrolę nad małżeństwem coraz wyraźniej przejmował Kościół ${ }^{3}$, co widoczne jest choćby w powszechnym nakłanianiu par do zawierania związku in facie Ecclesiae, a proboszczów do głoszenia zapowiedzi oraz w dalszej kolejności włączaniu wielu świeckich obyczajów w kościelną ceremonię. Przykładowo wspomniana ceremonia

${ }^{1}$ G. Duby, Rycerz, kobieta i ksiądz. Małżeństwo w feudalnej Francji, Warszawa 1986, s. 147-148, (oryg. franc. 1981).

2 L. Stomma, Rytuał pokładzin w Polsce. Analiza strukturalna, „Etnografia Polska” 19, 1975, 1, s. 51-52; A. Krawiec, Seksualność w średniowiecznej Polsce, Poznań 2000, s. 66-67; idem, Pożądanie i rytuał. Seksualność małżeńska w późnym średniowieczu, w: Manželství v pozdním středověku. Rituály a obyčeje, red. P. Kras, M. Nodl, Praha 2014 (Colloquia mediaevalia Pragensia 14), s. 241-242.

${ }^{3}$ Proces ten opisała w swojej pracy Ruth Mazo Karras, Unmarriages. Women, Men, and Sexual Unions in the Middle Ages, Philadelphia 2012, s. 25-67. 
pokładzin zamieniona została w obrzęd uroczystego poświęcenia łoża małżeńskiego przez kapłana ${ }^{4}$. Działania prewencyjne nie zawsze jednak spełniały swoją rolę, stąd należało stworzyć grupę zasad, które pozwoliłyby radzić sobie z problemami ujawnionymi już po zawiązaniu małżeństwa.

W średniowieczu przed sądami diecezjalnymi w całej chrześcijańskiej Europie niejednokrotnie stawały pary, z których jedna strona oskarżała drugą o to, iż ta po zawarciu związku okazała się być niezdolna do wypełniania cielesnych obowiązków małżeńskich. Z reguły sędzia - biskup lub oficjał - stawał przed trudną decyzją, jak pokierować zainteresowanymi. Czy związek należy uznać za nieważny, czy też może dać młodym więcej czasu, by mogli podjąć próby pokonania przeszkody, czy też tropić oszustów, którzy pragnąc po prostu rozejść się, zasłaniali się impotencją. W XIV i XV w. oficjałowie, coraz częściej stający przed koniecznością rozsądzenia skłóconych małżonków, mieli do pomocy kształtujące się dopiero, wciąż pełne kontrowersji prawo kościelne, tzw. prawo dekretałów, oraz wiedzę wynikającą ze świeckiej praktyki społecznej. Warto podkreślić, że pogodzenie tych dwóch sfer i wydanie wyroku nie było zadaniem łatwym, szczególnie w krajach takich jak Polska, gdzie praktyka życia codziennego świeckich była odległa od tej, dla której powstawały papieskie dekrety.

Żeby znaleźć odpowiedź na pytanie, czy niemoc płciowa jednego z małżonków może być powodem uznania za nieważne chrześcijańskiego, nierozerwalnego w swojej podstawowej definicji małżeństwa, wyrokujący musiał wiedzieć, jakie warunki należy wpierw spełnić, by związek mógł zostać uznany za ważnie zawarty. Choć dziś odpowiedź wydaje się prosta, to jednak średniowieczni prawnicy przez stulecia nie byli w stanie wypracować w tej kwestii wspólnego stanowiska. Aż do soboru w Trydencie aktywni byli zwolennicy dwóch różnych definicji określających, co stanowi o ważności małżeństwa. Teoria konsensualna (uznająca za wzór biblijne małżeństwo Maryi z Józefem i głosząca, iż złożona przez parę przysięga stanowi o pełnej ważności związku) i koitalna (wymagająca obietnicy potwierdzonej podjęciem współżycia dla uzyskania pełnej legalności związku) przenikały się w pismach moralizatorskich i prawniczych ${ }^{5}$.

${ }^{4}$ Opis obrzędu zob. choćby A. Krawiec, Pożądanie i rytuał, s. 243-244.

${ }^{5} \mathrm{Z}$ uwagi na rozmiary artykułu w tekście zaakcentowano jedynie podstawowe elementy polemiki pomiędzy tzw. szkołami paryską i bolońską. Podsumowanie przebiegu genezy obu teorii oraz wątków dyskusyjnych pomiędzy nimi zob. J.A. Brundage, Impotence, Frigidity and Marital Nullity in the Decretists and the Early Decretalists, w: Sex, Law and Marriage in the Middle Ages, Aldershot-Brookfield 1993, s. 407-423; zob. również Handbook of Medieval Sexuality, red. V. Bullough, J.A. Brundage, New York 1996. Z kolei 
Wielu teologów średniowiecznych poruszało kwestie związane z małżeństwem, biorąc pod uwagę również jego aspekt cielesny. Jednym z najważniejszych w grupie propagatorów idei małżeństwa, jako zawartego i ratyfikowanego wzajemną przysięgą, był Hugo od św. Wiktora. Autor traktatu na temat dziewictwa Maryi (De B(eate) Marie virginitate), podkreślał, że związek dwojga ludzi jest ważny już na podstawie wyrażonej zgody, nie zaś samej więzi cielesnej ${ }^{6}$. Kolejnym, niezwykle istotnym dla zmian, jakie w następnych wiekach miały następować w zagadnieniach prawnych dotyczących tej kwestii, było dzieło Gracjana Concordia discordantium canonum (zwane potocznie Dekretem), w którego drugiej części dziesięć rozdziałów poświęcono zagadnieniom matrymonialnym (tzw. Tractatus de matrimonio) ${ }^{7}$. Na podstawie rozważań tego autora przez kolejne stulecia budowano podstawy prawa kanonicznego. Gracjan, podsumowując wcześniejsze stanowiska teologów, określił, czym jest małżeństwo oraz co stanowi podstawę uznania je za ważne. Bardzo wyraźnie zaznaczył, iż dla potwierdzenia pełnej wartości związku niezbędne są dwa elementy, na które składają się wzajemna przysięga oraz podjęcie współżycia seksualnego. Wyrażając swoje stanowisko w ten sposób, stał się Gracjan czołowym zwolennikiem i propagatorem koitalnej teorii ważności małżeństwa. Związek zatwierdzony przysięgą uznawany był przez niego za zainicjowany, natomiast fizycznie skonsumowany można było nazwać potwierdzonym ${ }^{8}$. Według Gracjana jednak tylko

w polskiej literaturze naukowej M. Michalski, Coitus albo consensus, czyli co stanowi o ważności małżenstwa. Relacja z pewnej dyskusji z XI-XIII wieku, w: Nihil superfluum esse. Studia z dziejów średniowiecza ofiarowane Profesor Jadwidze Krzyżaniakowej, red. J. Strzelczyk, J. Dobosz, Poznań 2000, s. 159-163; A. Krawiec, Pożądanie i rytuał, s. 239-240.

${ }^{6}$ Hugonis de S. Victore, De B. Mariae virginitate, w: Patrologia Latina, t. 176, ed. nova, wyd. J.P. Migne, Parisiis 1880, szp. 858-876; M. Ozorowski, Zarys historyczny teologii małżenstwa w średniowieczu, „Studia Teologiczne. Białystok - Drohiczyn - Łomża” 14, 1996, s. 273.

7 Decretum magistri Gratiani, w: Corpus iuris canonici, ed. Lipsiensis secunda, wyd. A.L. Richter, instruxit A. Friedberg, pars prior, Lipsiae 1881 [Graz 1959], szp. 1047 nn., na ten temat zob. P. Hemperek, W. Góralski, Historia źródeł i nauki prawa kanonicznego, Lublin 1995 (Komentarz do kodeksu prawa kanonicznego z 1983 r., t. 1, cz. 1), s. 77-87.

${ }^{8}$ Corpus iuris canonici, c. 27 q. 2.1, szp. 1063; c. 29 q. 1, szp. 1091. W kwestii zagadnień z zakresu średniowiecznego prawa kościelnego odwołuję się przede wszystkim do opracowań, gdyż moim celem nie jest analiza samych tekstów, a jedynie podsumowanie wybranych treści. Szczegółowy obraz zmian w prawie kościelnym, w tym również znaczenie dzieła Gracjana, scharakteryzowano w pracach: J.T. Noonan, Marital Affection in the Canonists, "Studia Gratiana” 12, 1967, s. 481-483; J.A. Brundage, Concubinage and Marriage in Medieval Canon Law, "Journal of Medieval History" 1, 1975, 1, s. 7-8; idem, Law, Sex and Christian Society in Medieval Europe, Chicago 1990, s. 229-255; idem, The Problem of Impotence, w: Sexual Practices and the Medieval Church, red. V.L. Bullough, 
brak rozpoznania cielesnego zaistniały na początku związku, który nie pozwolił na jego inicjację, mógł stać się dla Kościoła powodem do uznania go za nieważny. Autor nie zajmował się natomiast kwestią impotencji, która mogła pojawić się w małżeństwie już skonsumowanym"

Chętnie cytowany przez współczesnych Dekret włoskiego kanonisty spotkał się ze sprzeciwem zwolenników teorii konsensualnej. Wśród tej grupy należy wyróżnić Piotra Lombarda i jego dzieło Sententiae, w którym jako pierwszy z autorów wyraźnie stawiał małżeństwo na równi z innymi sakramentami Kościoła ${ }^{10}$ i opowiadał się za tym, iż dla potwierdzenia jego powstania podstawowa jest wyrażona przez oboje małżonków zgoda na zawarcie związku; współżycie natomiast, stanowiąc co prawda oczywisty jego element, winno mieć dla uznania jego ważności znaczenie drugorzędne ${ }^{11}$.

Jako pierwszy próbę odgórnego rozstrzygnięcia sporu pomiędzy szkołami bolońską i paryską podjął Aleksander III (1159-1181) i to na jego

J. Brundage, Buffalo 1994, s. 135-140; idem, Impotence, Frigidity, s. 408-409; R. Mazo Karras, Seksualność w średniowiecznej Europie, Warszawa 2012 (oryg. ang. 2005), s. 102, a przede wszystkim E.M. Makowski, The Conjugal Debt and Medieval Canon Law, „Journal of Medieval History" 3, 1977, s. 99-114. Z kolei analizę zagadnienia dotyczącego obowiązku konsumpcji związku od prac Hinkmara do zaleceń Aleksandra III (1159-1181), a w dalszej kolejności Innocentego III (1198-1216) wraz z przykładami wykorzystania ich w praktyce sądowej przeprowadzili: G. Mathon, Le mariage des chrétiens, t. 1: Des origins au concile de Trente, Paris 1993, s. 187-260; D.L. d'Avray, Medieval Marriage. Symbolism and Society, Oxford 2005, s. 176-195; w pracach podsumowana także wcześniejsza literatura. Wśród polskich autorów zainteresowanie zagadnieniem było znacznie mniejsze, zob. M. Ozorowski, op. cit., s. 269-277; A. Krawiec, Seksualność, s. 35-37; idem, Pożądanie i rytuał, s. 240-241; M. Zawilski, Małżeństwo, kobieta, cielesność. Instytucja małżeństwa w XIIi XIII-wiecznej Francji, Kraków 2008, s. 68-69.

9 Podkreślał to m.in. J.A. Brundage, Impotence, Frigidity, s. 408-409, 413.

${ }^{10}$ Używanie słowa sakrament odnośnie do małżeństwa występowało w pracach wcześniejszych, jednak ostatecznie dogmat o sakramentalności małżeństwa przyjęto dopiero na soborze trydenckim, zob. Dokumenty soborów powszechnych. Tekst łaciński, polski, t. IV/1: (1511-1870), Lateran V, Trydent, Watykan I, układ i oprac. A. Baron, H. Pietras, Kraków 2007, s. 185-554 oraz t. IV/2, s. 555-870, a szczególnie s. 715-732, gdzie jest opis sesji 24, w czasie której rozważano sprawy sakramentu małżeństwa, Kanony o reformie małżeństwa (Tametsi). Więcej na temat powstawania kanonicznej formy małżeństwa zob. A. Tunia, Kształtowanie się kanonicznej formy zawarcia małżeństwa, „Roczniki Nauk Prawnych" 1, 2008, 18, s. 129-159.

${ }^{11}$ Magistri Petri Lombardi Parisiensis episcopi Sententiae in IV libris distinctae, Spicilegium Bonaventurianum 4-5, Grottaferrata 1971-1981, zob. też J.A. Brundage, Law, Sex, s. 262-268; A. Krawiec, Seksualność, s. 38; M. Michalski, op. cit., s. 163; M. Ozorowski, op. cit., s. 273 - w powyższych pracach przytoczono również wypowiedzi innych kanonistów i moralistów współczesnych, których osobna analiza na potrzeby niniejszego tekstu nie wydaje się konieczna. 
decyzjach w wielu wypadkach bazowali kolejni następcy św. Piotra ${ }^{12}$. W jednym z wczesnych znanych pism, skierowanym do biskupa Padwy Gerarda, pt. Sollicitudini Sedis ${ }^{13}$, papież wypowiedział się za jednoznacznością i nierozerwalnością umowy małżeńskiej raz zawartej, której nie rozwiązuje w żaden sposób kolejna zawarta umowa. Powściągliwy ton dekretału świadczyć może o wyraźnie zakorzenionych wręcz przeciwnych zwyczajach ${ }^{14}$. Kolejny raz głos papieża wybrzmiał w dekretale Licet praeter solitum ${ }^{15}$, stanowiącym odpowiedź dla arcybiskupa z Salerno. Czytamy, że consensus de praesenti, czyli dosłownie „wyrażona zgoda obecnie", z natychmiastowym skutkiem, sama z siebie powoduje zaistnienie formalnego związku małżeńskiego, nawet jeśli nie został on dopełniony współżyciem. Kwestia obietnicy, stanowiącej jednoznacznie o zawarciu małżeństwa, znajduje się także w liście papieża do biskupa Bath (Anglia) De illis, qui infra ${ }^{16}$. Aleksander III, zajmując się tutaj problemem związków, w których przynajmniej jedna ze stron pozostawała nieletnia, równocześnie określał zasady, kiedy możliwe było odstępstwo od wcześniej

12 Aleksander III i jego dekretały interesują nas szczególnie, gdyż po pierwsze był to jeden z nielicznych papieży, który wiele miejsca w swych pismach kierowanych do biskupów poświęcał kwestiom małżeńskim, po wtóre, większość postanowień kolejnych papieży na nim się opierała. W pewnej części dokumenty powstałe za jego sprawą zostały włączone w dekretały Grzegorza IX. Trudne do jednoznacznej interpretacji z uwagi na fakt, że sam ich autor zmieniał zdanie, dostosowując odpowiedzi do okoliczności. Jego decyzje zachowały się w formie odpowiedzi na różnorakie sytuacje prawne, co do których rady szukali biskupi poszczególnych diecezji. Dekretały Aleksandra III stanowią ciekawe i wciąż nie w pełni wykorzystane źródło do badań rodzącego się prawa kościelnego w zakresie małżeństw w średniowieczu. Ostatnio charakterystykę dużej grupy interesujących nas dekretałów papieskich oraz zebranie zagadnień dotyczących kwestii małżeńskich w Corpus Iuris Canonici przeprowadził Philip L. Reynolds, How Marriage Became One of the Sacraments. The Sacramental Theology of Marriage from its Medieval Origins to the Council of Trent, Cambridge 2016, s. 279 nn.

${ }^{13}$ Regesta pontificum romanorum ab condita Ecclesia ad annum post Christum natum MCXCVIII, t. 2, wyd. P. Jaffé, G. Wattenbach [et al.], Lipsiae 1888, nr 14235, s. 405; tu dalsze odniesienia źródłowe. Na temat zmian w podejściu do analizowanego zjawiska w dekretałach Aleksandra III zob. B.W. Zubert, Przeszkoda wieku do małżeństwa w dekretałach papieskich i nauce prawa $w$ drugiej połowie XII wieku, „Prawo Kanoniczne” 13, 1970, 3-4, s. 73-124, zwłaszcza s. 73-87; a szczególnie B. Kane, Impotence and Virginity in the Late Medieval Ecclesiastical Court of York, New York 2008 (Borthwick Paper 114), s. 6 nn., a także P.L. Reynolds, op. cit., s. 279-285.

${ }^{14}$ B.W. Zubert, op. cit., s. 73.

15 Regesta pontificum romanorum, nr 14091, s. 394; Decretalium Gregorii papae IX compilatio, w: Corpus iuris canonici, editio Lipsiensis secunda, wyd. A.L. Richter, instruxit A. Friedberg, pars secunda, Graz 1959, c. 3 X 4, 4 (szp. 680-681); na ten temat zob. B.W. Zubert, op. cit., s. 73-76, który przywołał również inne odpowiedzi Aleksandra III; P.L. Reynolds, op. cit., s. 281-282.

${ }^{16}$ Corpus iuris canonici, c. 7 X 4, 2 (szp. 675). 
wyrażonej zgody na małżeństwo i przyzwalał na nie tylko w przypadku małoletności. Jeśli natomiast małżonkowie składali obietnice jako pełnoletni, papież nie widział możliwości unieważnienia związku, podobnie jeśli został on dopełniony współżyciem przez niepełnoletnie, jednak dojrzałe już fizycznie osoby.

Z czasem juryści coraz wyraźniej podkreślali, iż najważniejszym owocem małżeństwa winno być wydanie na świat potomstwa, co jednoznaczne konfrontowało ich z koniecznością uwzględnienia w rozważaniach kwestii relacji cielesnej ${ }^{17}$. W związku z tym, poza teoretyczną definicją małżeństwa, prawo kościelne określało również bardziej szczegółowe kwestie związane z praktyką społeczną. Dla kleru mającego bezpośredni kontakt z parafianami, a w dalszej kolejności również dla sądów kościelnych, najważniejsze było jednoznaczne sformułowanie definicji i typów tzw. przeszkody małżeńskiej. Ich zakres i liczba ulegały przez wieki zmianom ${ }^{18}$. W dekrecie Aleksandra III Veniens ad nos wskazano podstawowe powody, dla których małżeństwo można było uznać za nieważne. Wśród nich istotne miejsce zajęła niezdolność do cielesnego skonsumowania związku $^{19}$. Na przełomie XII i XIII w. coraz wyraźniej krystalizował się podział na dwa rodzaje przeszkód - pierwsze określano jako zrywające (impedimentum dirimens), drugie zaś tamujące (impedimentum impediens). Te ostatnie stanowiły jedynie powód do ewentualnego ukarania winnych zawarcia związku, jednak nie dawały podstaw do stwierdzenia jego nieważności (divortium) ${ }^{20}$. Wśród nich najczęściej występowało niezachowanie formalnych, wskazanych przez prawo kościelne zasad, według których należało zawrzeć małżeństwo (w tym na przykład nieprzestrzeganie obowiązku zapowiedzi czy obecności kapłana oraz świadków podczas ceremonii). W grupie tej znajdowały się również umówione wcześniej zaręczyny, które nie zostały prawnie rozwiązane przed zawarciem małżeństwa z inną osobą.

17 E.M. Makowski, op. cit., s. 107. Autorka powołała się na kanonistów Rajmonda z Peñafort oraz Hortensiusa; J.A. Brundage, The Problem of Impotence, s. 135; M. Zawilski, op. cit., s. 70 .

18 S. Biskupski, Prawo małżeńskie Kościoła rzymskokatolickiego, t. 1, Warszawa 1956 (wyd. 1), s. 109-111; idem, Prawo małżeńskie Kościoła rzymskokatolickiego, t. 1: Teoria małżeństwa i prawo materialne, przyg. i uzup. zgodnie z prawem posoborowym M. Żurowski, Warszawa 1971 (wyd. 2), s. 128-130.

${ }^{19}$ Corpus iuris canonici, c. 15 X 4, 1 (szp. 666-667); J.A. Brundage, Impotence, Frigidity, s. $412-413$.

${ }^{20}$ Znaczenie terminu divortium w średniowieczu w oparciu m.in. o materiał źródłowy z polskich sądów kościelnych szczegółowo objaśniła Izabela Skierska, Rozwiązanie małżeństwa w Polsce późnego średniowiecza w świetle praktyki sądów kościelnych, w: Manželství v pozdním středověku, s. 35-52. 
Natomiast w grupie przeszkód, które mogły zostać uznane za podstawę do zerwania związku, wraz z rozwojem prawa kanonicznego zaczęły funkcjonować konkretne, nazwane już problemy (w okresie przedtrydenckim ich liczba wzrosła aż do 18), jednak nie były one powtarzane konsekwentnie we wszystkich prawach partykularnie ogłaszanych w poszczególnych krajach i diecezjach. Wśród nich do najważniejszych i wspólnych dla większości diecezji europejskich należały: impotencja i oziębłość płciowa, niepoczytalność (obłęd), brak właściwego wieku (dla dziewcząt określonego na 12, dla chłopców na 14 lat), udowodniony fakt, iż zgoda choćby jednego z małżonków wypowiedziana została w wyniku przymusu, różnica stanu, różnica w wyznawanej religii, przyjęte przez przynajmniej jedną ze stron święcenia kapłańskie, złożone śluby zakonne lub śluby czystości, przestępstwo, cudzołóstwo, nadmiernie bliskie pokrewieństwo, powinowactwo lub związek duchowy oraz naruszenie (obraza) uczciwości publicznej, czyli zgorszenie i skandal21.

W założeniach ogłoszonych w okresie pontyfikatu Innocentego III (1198-1216) po raz pierwszy pojawiło się wyraźne wskazanie, że małżeństwo może zostać rozwiązane z powodu trwającej impotencji, jednak, gdyby jej objawy zniknęły, małżonkowie powinni do siebie powrócić, traktując przysięgę jako wiążącą ${ }^{22}$. Niemoc płciowa uznawana była za jeden z powodów, dla których strona obciążona tą przypadłością nie powinna była zawierać związku małżeńskiego, gdyż nie była w stanie spełniać przypadających na ten stan obowiązków - zarówno tych łączonych z prokreacją, jak i tych związanych z zabezpieczeniem pary przed cudzołóstwem, odbywającym się poza związkiem uświęconym nierozerwalną obietnicąą. Ostatecznie jednoznacznie jako przeszkoda do zawarcia małżeństwa impotencja została opisana w dekretałach (Decretales) Grzegorza IX (1227-1241) zatwierdzonych w $1234 \mathrm{r}$. W księdze czwartej, traktującej w pełni o prawie małżeńskim, znajduje się osobna sekcja 15 zatytułowana De frigidis et maleficiatis, et impotentia coeundi ${ }^{24}$, w której szczegółowo określono, w jakich wypadkach problemy oziębłości i impotencji wpływają na niemożność zawarcia związku małżeńskiego lub stwierdzenie jego nieważności.

Zagadnienie niemożności podjęcia i realizowania zadania, jakim było współżycie małżeńskie, zarysowało się wyraźnie w praktyce sądów

${ }^{21}$ Analizę materiału przeprowadził Charles Donahue, Law, Marriage, and Society in the Later Middle Ages.Arguments about Marriage in Five Courts, Cambridge 2007, s. 18-19; w pracy również podana bogata bibliografia dotycząca omawianego zagadnienia.

${ }^{22}$ J.A. Brundage, Impotence, Frigidity, s. 416.

${ }^{23}$ Ch. Donahue, Law, Marriage, s. 20.

${ }^{24}$ Corpus iuris canonici, c. 1-7 X 4, 15 (szp. 704-708); S. Biskupski, op. cit. (wyd. 2), s. 220 . 
kościelnych. Wobec przybywających przed oblicze oficjała małżonków, skarżących się na niemoc partnera, sędzia zobowiązany był podjąć odpowiednie kroki zmierzające do wydania wyroku. Nade wszystko winien był przeprowadzić szczegółowe rozeznanie, odnoszące się zarówno do prawdomówności pary, jak i do ewentualnych przyczyn powstania zgłoszonych problemów. Wśród przyczyn wystąpienia kłopotów w tej delikatnej materii najczęściej stwierdzano impotencję wrodzoną, jednak mogła się ona również pojawić w wyniku wypadku, czarów czy problemów zdrowotnych. Stwierdzenie przez oficjała trwałej niemożności konsumpcji związku - od jego początku, ale też w okresie jego trwania - mogło zostać wykorzystane jako argument do uznania małżeństwa za nieważne. Z powodów naturalnych z czasem wyrosła przeszkoda, dziś określana w prawie kanonicznym jako bezwzględna, natomiast z przyczyn czasowych, jak wspomniane czary, wywodzi się określenie niemocy tzw. względnej ${ }^{25}$.

Wśród przykładowych procesów z sądu w Ely (Anglia) z drugiej połowy XIV w. James A. Brundage opisał sprawę, w której niejaki John Poynant ożeniony z Jean Sikon, okazawszy się, jak sam przyznał, impotentem, sam uwolnił swoją żonę i zawarł drugi związek, w którym wykazał się nie tylko zdrowiem, ale także możliwością zapłodnienia dziewczyny. Do sądu oboje małżonkowie przybyli już w towarzystwie nowych partnerów. Druga żona Poynanta, Isabel Pybel, była w widocznej ciąży, co do której upewniła wszystkich zgromadzonych, że jej sprawcą jest John. Sędzia po przeanalizowaniu całej sprawy zawyrokował, że działania małżonków uznać należy za cudzołóstwo i bigamię, a impotencja była swego rodzaju wymówką i przykrywką dla postępków niezgodnych z nauką Kościoła. Opisy podobnych przypadków podał w swojej pracy również Charles Donahue ${ }^{26}$.

Pytaniem pozostaje, w jaki sposób sędzia, przed którym stawała skonfliktowana para, mógł zyskać pewność, że deklarowana impotencja rzeczywiście występuje i że jest trwała. Jednym z podstawowych rozwiązań było zalecenie parze cierpliwości i pozostania razem jeszcze przez wyznaczony odgórnie czas. Ten wykorzystywany następnie przez wieki sposób sprawdzenia, czy istnieje konieczność unieważnienia związku, polegający właśnie na trzyletnim okresie próby, został po raz pierwszy zastosowany prawdopodobnie za pontyfikatu Honoriusza III $(1216-1227)^{27}$. Jakie dalsze rozwiązania przewidywało prawo? Zalecenia

25 S. Biskupski, op. cit. (wyd. 1), s. 171-172; idem, op. cit. (wyd. 2), s. 219-220; E.M. Makowski, op. cit., s. 106; Ch. Donahue, Law, Marriage, s. 20.

${ }^{26}$ J.A. Brundage, The Problem of Impotence, s. 138-139; Ch. Donahue, Law, Marriage.

27 J.A. Brundage, Impotence, Frigidity, s. 416. 
kanoniczne, w większości wspólne dla różnych diecezji europejskich, sugerowały przede wszystkim dużą ostrożność w kwestii orzecznictwa w tym zakresie. Uczeni badający sprawy z terenów dzisiejszej Francji i Wielkiej Brytanii zwrócili uwagę na fakt, iż postępowanie sądów było w pewnym stopniu zróżnicowane, pomimo wspólnych zaleceń odgórnych, a sędzia miał do wyboru cały wachlarz możliwości. Zazwyczaj sugerowano, poza wspomnianym wyżej trzyletnim okresem prób, zebranie zeznań oraz przysiąg stron, powołanie i wysłuchanie świadków, oględziny prowadzone przez wyznaczonych do tego zadania biegłych, którzy sprawdzali trzy elementy: dojrzałość, rozmiar oraz zdrowie i funkcjonalność narządów płciowych. W dalszej kolejności sędzia mógł zalecić parze zastosowanie wskazanych przez badających środków leczniczych ${ }^{28}$. Dopiero po spełnieniu wszelkich formalności i wykorzystaniu wszystkich możliwości kwestia impotencji stawała się dla sądu jednoznaczna ${ }^{29}$. Tak wnikliwe i rozciągnięte $\mathrm{w}$ czasie sprawdzanie było motywowane faktem, że sądownictwo dopuszczało możliwość istnienia tzw. impotencji czasowej lub ograniczonej do konkretnego partnera, a spowodowanej takimi czynnikami, jak czary czy rzucony urok. W takiej sytuacji okres oczekiwania i pozostałe środki zaradcze miały być dla małżonków szansą na walkę z problemem ${ }^{30}$.

Z podobnymi kłopotami par małżeńskich spotykali się także polscy sędziowie, jednak najwcześniejsze znane sprawy dotyczą dopiero początku XV w. Oficjał - urzędnik biskupa wypełniający swoje obowiązki w zakresie sądownictwa na terenie diecezji - był akceptowalną z chrześcijańskiego punktu widzenia osobą do szukania rozwiązania problemu

${ }^{28}$ S. Biskupski, op. cit. (wyd. 1), s. 172; J.A. Brundage, The Problem of Impotence, s. 135; idem, Impotence, Frigidity, s. 420-421; Ch. Donahue, Law, Marriage, s. 20; I. Skierska, Rozwiąanie małżeństwa, s. 48.

${ }^{29}$ Co prawda Georges Duby (op. cit., s. 147-148) opisał próbę sprawdzenia, czy impotencja mężczyzny jest pełna, poprzez pozostawienie go w sytuacji intymnej z inną kobietą niż jego małżonka, jednak warto podkreślić, iż nie znajdujemy w zaleceniach prawnych, tudzież w rozwiązaniach proponowanych przez sądy, sugestii przeprowadzania podobnych testów. Taki przykład w oparciu o analizę spraw konsystorza lwowskiego przedstawiła Aleksandra Książkiewicz, jednak w tym wypadku chodziło o badanie, czy kobieta zachowała dziewictwo oraz czy mężczyzna jest sprawny seksualnie, które miało odbyć się z udziałem osoby wyznaczonej, świadka, zob. A. Książkiewicz, Sprawy małżeńskie w konsystorzu lwowskim w późnym średniowieczu, „Nasza Przeszłość” 109, 2008, s. 297-298; na błędne tłumaczenie tekstu wydanego w: Acta Officii consistorialis Leopoliensis antiquissima, wyd. W. Rolny, t. 1, Lwów 1927, t. 1, Lwów 1930 (Zabytki Dziejowe, t. 2 i 3), nr 1314, s. 344-345 zwróciła wcześniej uwagę Izabela Skierska, Rozwiąanie małżeństwa, s. 48, przyp. 63.

${ }^{30}$ E.M. Makowski, op. cit., s. 106; J.A. Brundage, The Problem of Impotence, s. 136-137. 
przez skonfliktowanych małżonków, którzy mogli udać się do niego po pomoc w celu znalezienia wyjścia ze swoich kłopotów ${ }^{31}$. W polskich archiwach kościelnych przechowywane są setki spraw tego typu spisanych podczas sesji sądowych, które toczyły się w konsystorzu ${ }^{32}$.

Zagadnieniu procesów o stwierdzenie nieważności małżeństwa z powodu impotencji w polskich sądach kościelnych nie poświęcono do tej pory osobnych studiów. W pracach, które traktują o sądach konsystorskich lub zagadnieniach małżeństwa i seksualności w Polsce średniowiecznej, kwestię oziębłości płciowej charakteryzowano wyłącznie w oparciu o wymienione wyżej edycje źródłowe ${ }^{33}$. W kilku zaledwie

${ }^{31}$ Zob. M. Biniaś-Szkopek, Funkcjonowanie sąu konsystorskiego w Poznaniu w pierwszych latach XV wieku, w: Sacrum w mieście, t. 1: Średniowiecze i wczesna epoka nowożytna. Wymiar religijny, kulturalny i społeczny, red. D. Quirini-Popławska, Ł. Burkiewicz, Kraków 2016, s. 189-200; A. Kozak, Miejsca działalności konsystorza generalnego w Poznaniu i jego pisarzy w pierwszej ćwierci XV wieku, w: Loca scribendi. Miejsca i środowiska tworzace kulture pisma w dawnej Rzeczypospolitej XV-XVIII stulecia, red. A. Adamska, A. Bartoszewicz, M. Ptaszyński, Warszawa 2017, s. 126-151, w nich również podsumowanie wcześniejszej literatury.

32 Spośród nich tylko niewielki procent został wydany - większość pozostaje nadal w rękopisie. Zob. Acta capitulorum nec non iudiciorum ecclesiasticorum selecta, wyd. B. Ulanowski, t. 2: Acta iudiciorum ecclesiasticorum dioecesum Gnesnensis et Poznaniensis (14081530), Kraków 1902; zob. także Acta capitulorum nec non iudiciorum ecclesiasticorum selecta, wyd. B. Ulanowski, t. 1 i 3, Kraków 1894-1902-1908 (Monumenta medii aevi historica, t. 13, 16, 18); Acta capitulorum Cracoviensis et Plocensis selecta (1438-1523; 1438-1525), wyd. B. Ulanowski, 1891 (Archiwum Komisji Historycznej 6), s. 1-183; B. Ulanowski, O pracach przygotowawczych do historyi prawa kanonicznego w Polsce, Kraków 1887, s. 85-89; Laudum Vartense, wyd. B. Ulanowski, RWHF PAU 21, 1887; Praktyka w sprawach małżéskich $w$ sadach duchownych diecezji krakowskiej, wyd. B. Ulanowski, „Archiwum Komisji Historycznej" 5, 1889, s. 87-194; O pokucie publicznej w Polsce, wyd. B. Ulanowski, RWHF PAU 23, 1888; Acta Officii consistorialis Leopoliensis, t. 1 i 2; Cracovia artificum 1300-1500, wyd. J. Ptaśnik, Kraków 1917 (Źródła do Historii Sztuki i Cywilizacji w Polsce, t. 4); Cracovia artificum 1501-1550, zebrał J. Ptaśnik, do druku przyg. M. Friedberg, Kraków 1936, 1948 (Źródła do Historii Sztuki i Cywilizacji w Polsce, t. 4, 5, z. 1-2); Cracovia impressorum XV et XVI saeculorum, wyd. J. Ptaśnik, Lwów 1922 (Monumenta Poloniae Typographica, t. 1); Teksty źródłowe do dziejów kultury i sztuki z najdawniejszych oficjaliów krakowskich 1410-1412 oraz 1421-1424, wybrał i oprac. B. Przybyszewski, Wrocław 1985 (Cracovia artificum. Supplementa); Teksty źródłowe do dziejów kultury i sztuki z archiwaliów kurialnych $i$ kapitulnych w Krakowie 1433-1440, wybrał i oprac. B. Przybyszewski, Wrocław 1988; lata 1441-1450, Kraków 1993; lata 1451-1460, Kraków 2001; lata 1462-1475, Kraków 2000. Pełne i szczegółowe podsumowanie przeprowadziła Izabela Skierska, Źródła do badania praktyk religijnych w średniowiecznej Polsce. Akta sądów kościelnych i kapituł, „Archiwa, Biblioteki i Muzea Kościelne" 87, 2007, s. 180-192.

33 Zob. choćby P. Hemperek, Sprawy małżeńskie $w$ oficjalacie okręgowym $w$ Lublinie w XV w., „Roczniki Teologiczno-Kanoniczne” 17, 1970, 5, s. 35; A. Krawiec, Seksualność, s. 231, gdzie opisany ciekawy przykład impotencji spowodowanej czarami; 
wypadkach autorzy, odwołując się do materiałów rękopiśmiennych, opisywali wybrane, pojedyncze przykłady, z których część dotyczyła kwestii małżeńskich, a tylko nieliczne problemu impotencji ${ }^{34}$.

Za cel studiów wybrałam diecezję poznańską i zgromadzone w Archiwum Archidiecezjalnym w Poznaniu księgi, które prowadzone były od roku 1403 (niestety pierwsze wpisy zaginęły podczas II wojny światowej i dziś najstarsza zachowana księga rozpoczyna się notami datowanymi na 1404 r.). Zapisane gęsto karty ksiąg Acta causarum są obrazem szerokiej działalności i zakresu władzy oficjałów. Wśród setek różnorakich spraw historyk, czytając strona po stronie, wyłuskuje ukryte w kolejnych dniach procesowych pary małżeńskie, przybywające przed oblicze sędziego ze swymi problemami. Z uwagi na trudny do odszukania, a następnie do analizy materiał źródłowy, zestaw spraw wybranych do niniejszego artykułu obejmuje pierwsze ćwierćwiecze XV w., a więc księgi konsystorskie od AC 1 do AC 8 zbierające lata 1404-1425, z których jednak zaginęły zapisy z lat 1412-1416, natomiast karty z roku 1422 zachowały się jedynie we fragmentach. Księgi te składają się na ponad 2,5 tys. stron ukrywających, jak wskazuje kwerenda, 440 indywidualnych spraw małżeńskich, z których dokładnie 22 dotyczą zarzutów o impotencję ${ }^{35}$.

A. Książkiewicz, op. cit., s. 297-298, gdzie podany przykład z konsystorza lwowskiego; M. Delimata, „[...] ipsam idem dux tenerrime et omni affectu diligebat”, czyli o więziach matżeńskich w polskim średniowieczu (wybrane przykłady), w: Gospodarka, społeczeństwo, kultura $w$ dziejach nowożytnych. Studia ofiarowane Pani Profesor Marii Boguckiej, red. A. Karpiński, E. Opaliński, T. Wiślicz, Warszawa 2010, s. 91-101; eadem, „Mulieres suspectae” - przypadki niewiernych żon $w$ aktach sądów kościelnych, „Acta Universitatis Wratislaviensis” 177, 2008, s. 287-292; eadem, Wiarołomni mężowie przed polskimi sądami kościelnymi, „Nasza Przeszłość" 104, 2005, s. 247-258.

${ }^{34} \mathrm{~W}$ ostatnich latach przeprowadzono kilka drobniejszych prób analizy pojedynczych spraw, zob. A. Szymczakowa, Obrazki z życia małżeńskiego (i nie tylko) w Polsce centralnej w średniowieczu, w: Rycerze, wędrowcy, kacerze. Studia z historii średniowiecznej i wczesnonowożytnej Europy Środkowej, red. B. Wojciechowska, W. Kowalski, Kielce 2013; I. Skierska, Rozwiąanie małżeństwa, s. 48, gdzie podano przykłady wyroków wikariusza generalnego gnieźnieńskiego; A. Kozak, J. Łukaszewski, Osieczna i jej mieszkańcy w świetle najstarszych ksiag konsystorza poznańskiego (1404-1425), „Rocznik Leszczyński” 15, 2015, s. 53-67, gdzie autorzy przeprowadzili dodatkowo edycję wybranych zapisek; M. Biniaś-Szkopek, Kobiety, mężczyźni i małżeństwo w najstarszych księgach konsystorskich poznańskich, w: Kobieta i mężczyzna. Jedna przestrzeń - dwa światy, red. B. Popiołek, A. Chłosta-Sikorska, M. Gadocha, Kraków 2015, s. 27-36; eadem, Analiza małżeńskich sporów sądowych zanotowanych $w$ najstarszej księdze poznańskiego konsystorza, w: Stilo et animo. Prace historyczne ofiarowane prof. Tomaszowi Jasińskiemu w 65. rocznicę urodzin, red. M. Dorna, M. Matla, M. Sosnowski, E. Syska, Poznań 2016, s. 264-265.

35 Podziękowania winnam Tomaszowi Jurkowi, który wielokrotnie dopomagał mi w bojach z meandrami paleografii i łaciny średniowiecznej. To również on zainteresował mnie źródłami konsystorskimi, za co jestem mu niezmiennie wdzięczna. 
Nieustabilizowana jeszcze w tym okresie procedura sądowa, system spisywania not oraz zapewne niekompletność zachowanego materiału sprawiają, że opisy poszczególnych przypadków różnią się od siebie. W niektórych poznajemy jedynie samo oskarżenie, w kolejnych czytamy zapisany ręką pisarza wyrok, a tylko w nielicznej grupie szczęśliwie udało się prześledzić cały przebieg procesu.

Tabela 1. Liczba spraw dotyczących oskarżeń o impotencję, występująca w analizowanych księgach, w układzie chronologicznym

\begin{tabular}{|l|c|c|c|}
\hline \multicolumn{1}{|c|}{$\begin{array}{c}\text { Sygnatura } \\
\text { księgi }\end{array}$} & $\begin{array}{c}\text { Chronologia } \\
\text { księgi }\end{array}$ & $\begin{array}{c}\text { Spraw małżeńskich } \\
\text { ogółem }\end{array}$ & $\begin{array}{c}\text { Spraw } \\
\text { o impotencję }\end{array}$ \\
\hline AC 1 & $1404-1405$ & 32 & 2 \\
\hline AC 2 & $1406-1411$ & 52 & 0 \\
\hline AC 3 i 3a (księga wikariusza) & $1417-1423$ & 2 & 0 \\
\hline AC 4 & $1419-1420$ & 63 & 4 \\
\hline AC 5 & 1421 & 56 & 5 \\
\hline AC 6 & $1423-1424$ & 62 & 3 \\
\hline AC 7 & $1424-1425$ & 76 & 6 \\
\hline AC 8 & 1425 & 98 & 2 \\
\hline
\end{tabular}

Pierwsze zachowane sprawy dotyczące oskarżeń o impotencję zanotowane zostały w diecezji poznańskiej w $1405 \mathrm{r}$. W jednym z tych przypadków zapisano jedynie wyrok oficjała. Sądzia zdecydował się na stwierdzenie nieważności małżeństwa Osanny i Grzegorza z powodu jego impotencji, a jej samej zezwolił na zawieranie kolejnych związków (tabela 2, nr 1) ${ }^{36}$. Druga sprawa to zapis zgłoszonych przez Wichnę i Zygmunta problemów małżeńskich. Małżonka dla pewności podała sędziemu dwa powody, dla których jej zdaniem należałoby unieważnić jej związek z mężem. Po pierwsze Zygmunt, by się z nią związać, zdobył co prawda zgodę jej rodziców, jednak ona sama takowej nie wyraziła (generowało to przeszkodę przymusu). Dodatkowo, mimo ostatecznego połączenia, mężczyzna okazał się niezdolny do podjęcia współżycia. Niestety dalsze etapy sprawy nie znalazły odzwierciedlenia w księdze, poza informacją, że Zygmunt zaprzeczył oskarżeniom Wichny (tabela 2, nr 2).

${ }^{36}$ Odniesienia źródłowe do kolejnych opisywanych spraw znajdują się w stanowiącej część artykułu tabeli 2. O notach dotyczących impotencji z księgi AC 1 zob. M. Biniaś-Szkopek, Analiza małżeńskich sporów, s. 264-265. 
Tabela 2. Regesty spraw dotyczących oskarżeń o impotencję, występujących w analizowanych księgach (AC 1 - AC 8), w układzie chronologicznym

\begin{tabular}{|c|c|c|c|c|}
\hline $\mathrm{Nr}$ & Księga & Rok & Osoby & Treść not \\
\hline 1. & $\begin{array}{l}\text { AC } 1 \\
\text { k. } 127 \mathrm{a}\end{array}$ & 1405 & Osanna i Grzegorz & $\begin{array}{l}\text { Zapis wyroku w sprawie o impotencję, w której } \\
\text { sędzia uznał niemoc Grzegorza za powód stwier- } \\
\text { dzenia nieważności związku i zezwolił Osannie na } \\
\text { powtórny związek. }\end{array}$ \\
\hline 2. & $\begin{array}{l}\text { AC } 1 \\
\text { k. } 144 \mathrm{a}\end{array}$ & 1405 & $\begin{array}{l}\text { Wichna i Zygmunt } \\
\text { sukiennik }\end{array}$ & $\begin{array}{l}\text { Wichna oskarżyła Zygmunta o to, że pojął ją za } \\
\text { żonę bez jej zgody, jednak za wiedzą jej rodziców. } \\
\text { Ostatecznie według jej słów Zygmunt okazał się } \\
\text { impotentem. Mąż zaprzeczył. Sędzia wyznaczył } \\
\text { czas na obustronne przeprowadzenie dowodu. } \\
\text { Brak dalszych not. }\end{array}$ \\
\hline 3. & $\begin{array}{l}\text { AC } 4 \\
\text { k. } 164\end{array}$ & 1420 & $\begin{array}{l}\text { Agnieszka } \\
\text { z Glinna i Michał }\end{array}$ & $\begin{array}{l}\text { Agnieszka zeznała, że zawarła małżeństwo z Mi- } \\
\text { chałem w obliczu Kościoła, jednak on okazał się } \\
\text { impotentem z powodu czarów. Sędzia zarządził } \\
\text { trzyletni okres prób i jeśli nic się nie zmieni para } \\
\text { ma wrócić do sądu. Brak dalszych not. }\end{array}$ \\
\hline 4. & $\begin{array}{l}\text { AC } 4 \\
\text { k. } 186 \mathrm{~V}\end{array}$ & 1420 & Święchna i Michał & $\begin{array}{l}\text { Święchna oskarżyła Michała o niedojrzałość na- } \\
\text { rządów płciowych. Sędzia po przeprowadzeniu } \\
\text { badania nakazał im dalsze próby i pozostanie } \\
\text { w małżeństwie. }\end{array}$ \\
\hline 5. & $\begin{array}{l}\text { AC } 5 \\
\text { k. } 9 \\
9 \mathrm{v}, 10\end{array}$ & 1421 & $\begin{array}{l}\text { Barbara z Dolska } \\
\text { i Jan Pszenica } \\
\text { rzemieślnik ze } \\
\text { Śremu }\end{array}$ & $\begin{array}{l}\text { Barbara oskarżyła Jana o impotencję, Jan zaprze- } \\
\text { czył, zawiązano spór. Brak dalszych not. }\end{array}$ \\
\hline 6. & $\begin{array}{l}\text { AC 5, } \\
\text { k. } 37\end{array}$ & 1421 & $\begin{array}{l}\text { Paulina i Wojciech } \\
\text { z Konina }\end{array}$ & $\begin{array}{l}\text { Zapis wyroku uznającego za nieważne małżeń- } \\
\text { stwo Pauliny z Wojciechem oraz dającego jej moż- } \\
\text { liwość zawarcia nowego związku. Wyrok został } \\
\text { uzasadniony impotencją Wojciecha, spowodowa- } \\
\text { ną czarami, który po trzech latach prób nakaza- } \\
\text { nych przez sąd nie zdołał rozpoznać swej żony } \\
\text { cieleśnie. Z kolei ona po badaniu przeprowadzo- } \\
\text { nym przez uczciwe matrony okazała się nietknię- } \\
\text { ta fizycznie. }\end{array}$ \\
\hline 7. & $\begin{array}{l}\text { AC } 5 \\
\text { k. } 67\end{array}$ & 1421 & $\begin{array}{l}\text { Stanisława } \\
\text { z Biechowa } \\
\text { i Marcin } \\
\text { z Biechowa }\end{array}$ & $\begin{array}{l}\text { Zapis dalszego ciągu sprawy, w której po oskarże- } \\
\text { niu Marcina przez Stanisławę o impotencję sędzia } \\
\text { sprawdził, że mąż jest sprawny fizycznie, zdolny } \\
\text { do współżycia i wypełniania obowiązków małżeń- } \\
\text { skich. Brak wcześniejszych oraz dalszych not. }\end{array}$ \\
\hline 8. & $\begin{array}{l}\text { AC 5, } \\
\text { k. } 81\end{array}$ & 1421 & $\begin{array}{l}\text { Katarzyna } \\
\text { z Płowiec i Jan } \\
\text { z Płowiec }\end{array}$ & $\begin{array}{l}\text { Zastępca sędziego wysłuchał zeznań Katarzy- } \\
\text { ny o tym, że Jan obecnie deklaruje impotencję } \\
\text { z powodu czarów, tymczasem ona zaznaczyła, że } \\
\text { wcześniej z nią współżył. Sędzia nakazał pozosta- } \\
\text { nie w małżeństwie i kolejne próby. Brak dalszych } \\
\text { not. }\end{array}$ \\
\hline
\end{tabular}




\begin{tabular}{|c|c|c|c|c|}
\hline $\mathrm{Nr}$ & Księga & Rok & Osoby & Tresśc not \\
\hline 9. & $\begin{array}{l}\text { AC 6, } \\
\text { k. 39/ } \\
\text { AC 7, } \\
\text { k. } 80 \mathrm{v}\end{array}$ & $\begin{array}{l}1423 \\
1424\end{array}$ & $\begin{array}{l}\text { Machna z Pyzdr } \\
\text { i Jan z Nowej Wsi }\end{array}$ & $\begin{array}{l}\text { Jan zeznał, że z Machną są małżeństwem od } \\
\text { dwóch lat i żyją w jednym domu i dzielą jedno łóż- } \\
\text { ko. Z kolei Machna stwierdziła, że we wskazanym } \\
\text { czasie on okazał się impotentem i chce stwierdze- } \\
\text { nia nieważności ich małżeństwa. Sędzia po roku } \\
\text { nie znalazł jednak powodów do przeprowadzenia } \\
\text { tej procedury i nakazał im dalej próbować stano- } \\
\text { wić jedno ciało. Brak dalszych not. }\end{array}$ \\
\hline 10. & $\begin{array}{l}\text { AC 6, } \\
\text { k. 40v }\end{array}$ & 1423 & $\begin{array}{l}\text { Jagna i Maciej } \\
\text { z Siernik }\end{array}$ & $\begin{array}{l}\text { Jagna oskarżyła męża o impotencję, on potwier- } \\
\text { dził, że przed dziewięciu laty zawarli małżeństwo } \\
\text { i przez dwa lata spali w jednym łóżku i przez ten } \\
\text { okres on nie zdołał rozpoznać jej cieleśnie. Sędzia } \\
\text { nakazał jeszcze rok prób, potem, jeśli będą nie- } \\
\text { udane, para ma powrócić przed oblicze oficjała. } \\
\text { Brak dalszych not. }\end{array}$ \\
\hline 11. & $\begin{array}{l}\text { AC 6, } \\
\text { k. } 85\end{array}$ & 1423 & $\begin{array}{l}\text { Jadwiga ze Słupcy } \\
\text { i Stanisław } \\
\text { z Poznania }\end{array}$ & $\begin{array}{l}\text { Jadwiga zeznała, że jej mąż jest impotentem } \\
\text { i wniosła o stwierdzenie nieważności małżeństwa. } \\
\text { Stanisław potwierdził zeznanie żony. Sędzia na- } \\
\text { kazał im do świąt wielkanocnych żyć razem, mieć } \\
\text { wspólną kasę, traktować się z miłością i dzielić } \\
\text { łoże. Brak dalszych not. }\end{array}$ \\
\hline 12. & $\begin{array}{l}\text { AC 6, } \\
\text { k. } 90 \mathrm{v} \\
92 \mathrm{v}\end{array}$ & 1423 & $\begin{array}{l}\text { Agnieszka } \\
\text { z Wierzenicy } \\
\text { i Michał } \\
\text { Niewswodek (sic!) } \\
\text { z Wierzenicy }\end{array}$ & $\begin{array}{l}\text { Agnieszka i Michał zeznali, że z powodu braku } \\
\text { możliwości współżycia wnoszą o stwierdzenie nie- } \\
\text { ważności ich małżeństwa. Na udowodnienie przy- } \\
\text { prowadzili sześciu świadków, których sędzia wy- } \\
\text { słuchał, po czym uznał ich związek za nieważnie } \\
\text { zawarty, uzasadniając wyrok impotencją Michała. }\end{array}$ \\
\hline 13. & $\begin{array}{l}\text { AC 6, } \\
\text { k. } 98\end{array}$ & 1423 & $\begin{array}{l}\text { Anna i Długi } \\
\text { Maczek, chłop } \\
\text { (rusticus) }\end{array}$ & $\begin{array}{l}\text { Długi Maczek zeznał, że są z Anną małżeństwem } \\
\text { od sześciu lat i w tym czasie on wielokrotnie roz- } \\
\text { poznał ją cieleśnie, co ona potwierdziła, jednak } \\
\text { dodała, że od roku Maczek jest impotentem. Sę- } \\
\text { dzia zasądził rok prób, jeśli nic się nie zmieni para } \\
\text { ma do niego powrócić. Brak dalszych not. }\end{array}$ \\
\hline 14. & $\begin{array}{l}\text { AC 7, } \\
\text { k. } 80 \mathrm{v}\end{array}$ & 1424 & $\begin{array}{l}\text { Anna ze Szczytnik } \\
\text { i Mikołaj } \\
\text { Wojciechowy ze } \\
\text { Skrzynek }\end{array}$ & $\begin{array}{l}\text { Anna zeznała, że Mikołaj jest impotentem, a on } \\
\text { sam zaprzeczył. Sędzia zasądził dwuletni okres } \\
\text { sprawdzianu, w czasie którego para ma usilnie } \\
\text { próbować współżyć, jeśli problem będzie trwał, } \\
\text { małżonkowie mają wrócić przed oblicze oficjała. } \\
\text { Brak dalszych not. }\end{array}$ \\
\hline 15. & $\begin{array}{l}\text { AC 7, } \\
\text { k. } 89\end{array}$ & 1424 & $\begin{array}{l}\text { Stachna } \\
\text { Andrzejowa } \\
\text { i Wojciech z Góry }\end{array}$ & $\begin{array}{l}\text { Stachna zeznała, że od dwóch lat żyje w małżen- } \\
\text { stwie z Wojciechem i do tej pory on nie rozpoznał } \\
\text { jej cieleśnie, czego powodem jest jego impotencja. } \\
\text { Sam Wojciech przyznał, iżani ze Stachną, ani z żad- } \\
\text { ną inną kobietą nigdy nie współżył. Sędzia nakazał } \\
\text { w określonym terminie podjąć próby pełnego po- } \\
\text { życia małżeńskiego, jeśli się nie powiodą, mają po- } \\
\text { wrócić przed oblicze oficjała. Brak dalszych not. }\end{array}$ \\
\hline
\end{tabular}




\begin{tabular}{|c|c|c|c|c|}
\hline $\mathrm{Nr}$ & Księga & Rok & Osoby & Tresśc not \\
\hline 16. & $\begin{array}{l}\text { AC 7, } \\
\text { k. 191v }\end{array}$ & 1424 & $\begin{array}{l}\text { Małgorzata } \\
\text { z Moraska } \\
\text { i Mikołaj } \\
\text { z Suchego Lasu }\end{array}$ & $\begin{array}{l}\text { Małgorzata zeznała, że zawarli małżeństwo z Mi- } \\
\text { kołajem, po czym on okazał się impotentem, dla- } \\
\text { tego złożyła wniosek o stwierdzenie nieważności } \\
\text { ich małżeństwa. Mikołaj wszystkiemu zaprzeczył. } \\
\text { Sędzia nakazał parze rok prób, jeśli te się nie po- } \\
\text { wiodą, małżonkowie mają wrócić przed oblicze } \\
\text { oficjała. Brak dalszych not. }\end{array}$ \\
\hline 17. & $\begin{array}{l}\text { AC } 8, \\
\text { k. } 55\end{array}$ & 1425 & $\begin{array}{l}\text { Małgorzata } \\
\text { Wojciechowa } \\
\text { ze Świerczyna } \\
\text { i Frączek } \\
\text { z Osiecznej }\end{array}$ & $\begin{array}{l}\text { Wyznaczony prokurator w imieniu Małgorzaty } \\
\text { wniósł o stwierdzenie nieważności małżeństwa } \\
\text { z Frączkiem z powodu jego impotencji. Po roku } \\
\text { życia w małżeństwie mąż miał według jej słów nie } \\
\text { rozpoznać jej cieleśnie. Dalszy ciąg sprawy został } \\
\text { oddarty, brak dalszych not. }\end{array}$ \\
\hline 18. & $\begin{array}{l}\text { AC 8, } \\
\text { k. } 106\end{array}$ & 1425 & \begin{tabular}{|l|} 
Święchna, wdowa \\
po zmarłym \\
Marcinie z Długiej \\
Gośliny i Jakub \\
z Długiej Gośliny
\end{tabular} & $\begin{array}{l}\text { Jakub zeznał, że odszedł od Święchny z powodu } \\
\text { swojej impotencji, gdyż nie mógł rozpoznać jej } \\
\text { cieleśnie. Sędzia zasądził trzy lata prób, zanim po- } \\
\text { dejmie decyzję i wyda wyrok. Brak dalszych not. }\end{array}$ \\
\hline 19. & $\begin{array}{l}\text { AC 8, } \\
\text { k. } 123\end{array}$ & 1425 & $\begin{array}{l}\text { Stachna ze } \\
\text { Skórzewa } \\
\text { i Wojciech } \\
\text { mieszczanin } \\
\text { (oppidanus) ze } \\
\text { Skórzewa }\end{array}$ & $\begin{array}{l}\text { Para małżeńska zeznała, że zawarli związek w ob- } \\
\text { liczu Kościoła, jednak mają problemy z podjęciem } \\
\text { współżycia. Sędzia nakazał, iż jeszcze przez rok } \\
\text { mają podejmować próby, zanim on podejmie de- } \\
\text { cyzje i wyda wyrok. Brak dalszych not. }\end{array}$ \\
\hline 20. & $\begin{array}{l}\text { AC } 8, \\
\text { k. } 138 \mathrm{~V}\end{array}$ & 1425 & $\begin{array}{l}\text { Stasza } \\
\text { z Krzyżanowa } \\
\text { i Michał }\end{array}$ & $\begin{array}{l}\text { Stasza zeznała, że Michał jest impotentem, jednak } \\
\text { sędzia pod karami kościelnymi nakazał im pozo- } \\
\text { stać dalej ze sobą, podejmując próby współżycia. } \\
\text { Brak dalszych not. }\end{array}$ \\
\hline 21. & $\begin{array}{l}\text { AC } 8, \\
\text { k. } 260 \mathrm{v}\end{array}$ & 1425 & $\begin{array}{l}\text { Agnieszka } \\
\text { z Podrzewia } \\
\text { i Piotr krawiec } \\
\text { (sartor) z Pniew }\end{array}$ & $\begin{array}{l}\text { Agnieszka złożyła pozew o stwierdzenie nieważ- } \\
\text { ności jej małżeństwa z Piotrem z powodu jego im- } \\
\text { potencji. Zeznała, że zawarli małżeństwo w obliczu } \\
\text { Kościoła w Podrzewiu przed ostatnimi żniwami } \\
\text { (sprawa toczyła się w grudniu). Ona była dziewicą } \\
\text { i to dziewictwo przez niego nie zostało naruszone. } \\
\text { Piotrjednak zaprzeczył swej impotencji. Sędzia na- } \\
\text { kazał, iżjeszcze przez rok mają podejmować próby, } \\
\text { zanim on podejmie decyzję i wyda wyrok. Dodat- } \\
\text { kowo ustalił poręczenie na życie Agnieszki w wy- } \\
\text { sokości } 20 \text { grzywien oraz kar kościelnych, gdyby } \\
\text { ją Piotr zranił lub okaleczył. Brak dalszych not. }\end{array}$ \\
\hline 22. & $\begin{array}{l}\text { AC 8, } \\
\text { k. } 265\end{array}$ & 1425 & $\begin{array}{l}\text { Jadwiga } \\
\text { z Poznania } \\
\text { i Przybysław }\end{array}$ & $\begin{array}{l}\text { Jadwiga zeznała, że przez słowo (per verba de } \\
\text { praesenti) zawarli z Przybysławem małżeństwo } \\
\text { i w obliczu Kościoła je następnie potwierdzili. Te- } \\
\text { raz jednak ona wnosi o uznanie związku za nie- } \\
\text { ważny z powodu impotencji męża. On zaprzeczył. } \\
\text { Sędzia nakazał mu nie kaleczyć i nie ranić żony } \\
\text { i pozostać razem pod groźbą kar kościelnych. Brak } \\
\text { dalszych not. }\end{array}$ \\
\hline
\end{tabular}


Po tych dwóch zapisach w księgach konsystorskich diecezji poznańskiej następuje piętnastoletnia luka, nie znaleziono żadnych not powołujących się na impotencję lub oziębłość współmałżonka. Wszelkie inne problemy występują - znajdujemy sprawy dotyczące zbyt bliskiego pokrewieństwa pary, bigamii, niedotrzymania złożonych obietnic, przymusu zawarcia związku czy nadmiernej przemocy, a nawet prób zabicia żony lub męża. Czy jest to związane $\mathrm{z}$ faktem niepełnego zachowania materiału źródłowego, nietrafiania podobnych kwestii przed trybunał oficjała poznańskiego $\mathrm{w}$ tym czasie, czy też może z jakiegoś powodu nieprzyjmowania przez niego tego typu spraw - trudno dziś dociec.

Kolejne zapisy pochodzą dopiero z roku 1420, w którym do sądu na Ostrowie Tumskim w Poznaniu zgłosiły się dwie pary z problemem impotencji. W roku 1421 były cztery, w 1423 pięć, w kolejnym trzy i w roku 1425 sześć par małżeńskich. Warto w tym miejscu zaznaczyć, że osoby te trafiały zarówno przez oblicze samego oficjała, jak i były też sądzone przez jego zastępcę (tabela 2, nr 8). W większości wypadków poznajemy i sprawę, i pierwszą decyzję oficjała co do postępowania małżonków. W dwóch przypadkach zapisany został jedynie wyrok (tabela 2, nr. 1, 6). W kolejnych dwóch w jednej nocie znajdujemy opis przebiegu działań podjętych przez oficjała wraz z wydaniem wyroku (tabela 2 , nr. 9, 12).

We wszystkich odczytanych przypadkach powódkami były kobiety, które oskarżały swych współmałżonków o impotencję. Brak dla tego okresu procesów, w których to mężczyźni mieliby podobne uwagi względem swych żon, skarżąc się na oziębłość lub fizyczną niemożność skonsumowania związku ${ }^{37}$. Wśród przyczyn impotencji nierzadko wskazywane były czary (tabela $2, \mathrm{nr} .3,6,8$ ), jednak równolegle wiele petycji dotyczących niemocy płciowej podanych zostawało bez wyraźnego określenia ich przyczyny, która zapewne pozostawała nieznana małżonkom. W jednej ze spraw (tabela 2, nr 4) Święchna nie oskarżyła swego męża o impotencję jako taką, a o niedojrzałość narządów płciowych, określając w ten sposób źródło problemu. Oficjał zalecił przeprowadzenie badania, które jednak nie potwierdziło diagnozy kobiety. Nie jesteśmy w stanie stwierdzić na podstawie omawianego materiału źródłowego, czym według skarżących miała różnić się impotencja spowodowana czarami od

37 Takie wypadki zdarzały się dość rzadko, jednak przykłady są uchwytne również w polskim sądownictwie kościelnym. Jednym z najciekawszych jest sprawa wydana przez Bolesława Ulanowskiego, zob. Praktyka w sprawach małżeńskich, nr 7, s. 94-95, gdzie umieszczono zeznania matron przeprowadzających badanie w sprawie wadliwej budowy błony dziewiczej, która uniemożliwiała podjęcie współżycia. 
tej, która nie miała takiej przyczyny ${ }^{38}$. Zapewne częściej urok podawano jako powód, kiedy niemoc pojawiła się nagle w trwającym już, wcześniej normalnie funkcjonującym związku.

Decyzje poznańskiego oficjała bywały różne i świadczą o pełnej znajomości zaleceń prawa kościelnego przez polskich urzędników. Sędziowie zaczynali od przeprowadzenia dowodu w postaci przesłuchania świadków, stosowali zalecenie okresu prób aż po nakazanie badania i wyznaczenie biegłych, a następnie szczegółowe wysłuchanie tych, którzy winni podjąć się tego zadania. Świadków bywało wielu, gdyż wersja pary musiała zostać potwierdzona ponad wszelką wątpliwość. W jednym przypadku (tabela 2, nr 12) było ich sześciu i najprawdopodobniej tylko na ich zeznaniu sędzia oparł swoją decyzję o stwierdzeniu nieważności małżeństwa Agnieszki i Michała z Wierzenicy z powodu jego impotencji. W przypadku tej sprawy - być może temat nie był nowy, o czym świadczy wyjątkowo trafny przydomek nadany mężczyźnie, który był na tyle trwały, iż został uwieczniony w piętnastowiecznym rękopisie. Michał „Niewswodek” z Wierzenicy, którego impotencję potwierdziła żona i świadkowie, musiał zapewne stawiać czoła problemowi, zanim jeszcze stawił się przed poznańskim sądem kościelnym.

Zalecany czas prób w praktyce stosowanej przez poznańskich oficjałów wahał się od kilku miesięcy do trzech lat, w czasie których para miała sypiać w jednym łóżku i podejmować starania, by połączyć się w ,jedno ciało". Nie jesteśmy w stanie w pełni określić, od czego zależała długość wyznaczonego terminu prób. Prawdopodobnie sędzia brał pod uwage zarówno dotychczasowy staż związku, wiek pary, jak i inne przesłanki, wynikające z przesłuchania ewentualnych świadków. Najczęściej, jeśli nie zachodziły jakieś nietypowe okoliczności, sprawdzanie ograniczyć miało się do około roku (zob. tabela 2, nr 9 - para po dwóch latach związku, nr 10 - po dziewięciu latach, nr 13 - po sześciu latach, nr 16 - po czterech latach od zawarcia małżeństwa, w czasie których rok pozostawali razem, nr 19 - para z kilkumiesięcznym stażem, 21 - para z około półrocznym stażem). W jednym przypadku sędzia wyznaczył czas do świąt wielkanocnych, co zważywszy na fakt, iż rozprawa toczyła się we wrześniu, daje nam

38 Ruth Mazo Karras (Seksualność, s. 103-104) zauważyła, niestety bez określenia podstawy swoich rozważań, że działanie czarów brano pod uwagę, jeżeli impotencja mężczyzny występowała jedynie w stosunkach z jedną, konkretną kobietą - jego małżonką, natomiast ustępowała przy innych partnerkach. Lekiem zalecanym przez urzędnika sądowego miały być spowiedź i pokuta, które winny zrzucić urok. W materiale polskim nie znajdujemy podobnego wyjaśnienia impotencji spowodowanej czarami ani zaleceń, o których wspomniała ta autorka. 
około półroczny okres próby ${ }^{39}$. Innym razem sędzia z nieznanych przyczyn zalecił dwa lata (tabela 2, nr 14). Jest także kilka spraw, w których albo z powodu błędu pisarza, albo z innych względów formalnych czas karencji nie został zapisany, a małżonkowie zostali po prostu odesłani w celu dalszych prób podejmowania działań prokreacyjnych (tabela 2, nr. 4, 8, 22 oraz nietypowa sprawa $\mathrm{z}$ nr. 15 - małżonkowie mają podjąć próby w „określonym terminie”). Okres trzyletni ustalano najczęściej, gdy w oskarżeniu o impotencję pojawiało się dodatkowo podejrzenie o zauroczenie (zob. tabela. 2, nr. 3, 6). Wydaje się, że w takich wypadkach sędzia świadomie wydłużał okres karencji, by dać parze więcej czasu na odnalezienie ewentualnych winnych i odczynienie uroku. Podobnie długi czas zasądzono, kiedy to sam mężczyzna, deklarując swoją impotencję, odszedł od żony (tabela 2, nr 18). Jeśli po zadanym okresie prób nie udałoby się im podjąć współżycia, mieli powrócić przed oblicze sędziego.

Wśród spraw znalezionych w aktach konsystorza poznańskiego znajduje się zapis wyroku (tabela 2, nr 6), który dokładnie pokazuje przebieg całego postępowania oficjała. W roku 1421 Paulina i Wojciech z Konina wrócili przed oblicze sędziego po trzech latach zarządzonych wcześniej przez niego prób. Z prostego rachunku wynika, iż po raz pierwszy przybyli do sądu na Ostrowie Tumskim w Poznaniu w 1419 r., jednak zapisu z tego okresu nie znajdujemy w aktach kościelnych diecezji. Kiedy małżonkowie po okresie prób nadal deklarowali impotencję Wojciecha, zostali poddani szczegółowemu badaniu, które rzeczywiście wykazało, iż zapewne z powodu czarów mąż nie rozpoznał Pauliny cieleśnie, a ona sama pozostała dziewicą, jak zapewniły oficjała wyznaczone przez niego do przeprowadzenia oględzin uczciwe matrony. Tak poinformowany sąd zdecydował się na uznanie związku za nieważnie zawarty.

Warto zauważyć, że nie we wszystkich przypadkach sędzia posuwał się do tak długiego dowodzenia. Przykładowo w sprawie oznaczonej w tabeli 2 nr. 7 - która z nieznanych nam przyczyn wydała się oficjałowi prostsza - sprawdzenie narządów oskarżonego o niemoc płciową męża Marcina przeprowadzone zostało od razu, na jednej sesji i uznano go za w pełni sprawnego do wypełniania małżeńskich obowiązków, a parze zalecono pozostanie razem. Podobnie w sprawie pomiędzy Machną z Pyzdr a Janem pochodzącym z Nowej Wsi (tabela 2, nr 9), po zaleceniu rocznego okresu prób sędzia, pomimo faktu, iż wrócili oni przed oblicze oficjała, nie dopatrzył się uchybień i nakazał im trwanie w małżeństwie.

W znalezionym materiale znajduje się także kilka spraw wątpliwych, w których fakt impotencji był prawdopodobnie tylko pretekstem do

${ }^{39}$ AC 6, k. 85. 
próby uwolnienia się od uciążliwego współmałżonka. W jednej z nich Katarzyna z Płowiec skarżyła się sędziemu na to, że jej małżonek Jan nagle zadeklarował impotencję spowodowaną czarami i zaprzestał współżycia (tabela 2, nr 8). W tym przypadku oficjał nawet nie zalecił badania, tylko kazał parze pozostać ze sobą i wypełniać wzajemnie swoje obowiązki. Podobną sprawą wydaje się nagłe odejście od Święchny jej męża Jakuba, który, deklarując własną impotencję, po prostu ją opuścił. W tym przypadku sąd uznał, że kwestia wymaga dłuższego rozpoznania i zalecił okres aż trzech lat prób (tabela 2, nr 18) - tym samym powrót męża do żony minimum na ten czas.

W grupie analizowanych przez nas przypadków znajdują się jeszcze dwa, w których decyzje sędziego pokazują, iż miał on pewne wątpliwości co do ewentualnego bezpieczeństwa żony. W sprawach o numerach 21 i 22 oficjał, zalecając okres prób dla pary, dodatkowo wprowadził procedurę charakterystyczną dla przypadków zgłaszania przemocy małżeńskiej. W pierwszym procesie dziewica Agnieszka z Podrzewia miała być chroniona przed swym małżonkiem Piotrem, krawcem z Pniew. Pod groźbą poręczenia w wysokości 20 grzywien oraz kar kościelnych zabroniono mężczyźnie nastawać na jej życie i kaleczyć ją. W drugiej z omawianych spraw sędzia nakazał podjęcie współżycia, jednak Przybysławowi z Poznania zabronił pod karami kościelnymi ranienia i okaleczania małżonki Jadwigi.

Sądowe księgi kościelne, szczególnie te z okresu średniowiecza, to niezwykle ciekawe i do dziś wciąż w niewielkim stopniu wykorzystane źródło do badań nad społeczeństwem, małżeństwem i jego problemami, a także elementami życia codziennego tej epoki. Charles Donahue podkreślał, iż zanotowanych na kartach ksiąg, składających się na ten ogromny materiał, a przechowywanych w archiwach wielu krajów Europy spraw są dziesiątki tysięcy - tymczasem „robotników mało”, a „życie zbyt krótkie", by historyk mógł je wszystkie przeanalizować ${ }^{40}$. Powolnie odkrywane historie pomagają nam wejść głęboko w przestrzeń życia codziennego świeckich i to tych pochodzących często z niższych warstw społecznych, o których niewiele wiemy, i być może podjać próbę nakreślenia nieco skromniejszej, ale równie ciekawej panoramy, jaką w swej legendarnej już pracy stworzył Emmanuel Le Roy Ladurie dla wsi Montaillou ${ }^{41}$.

${ }^{40}$ Ch. Donahue, Law, Marriage, s. 7.

${ }^{41}$ E. Le Roy Ladurie, Montaillou. Wioska heretyków 1294-1324, przedm. E. Domańska, Czerwonak 2014 (oryg. franc. 1982). Podobnego porównania, charakteryzując jedną 
Odkrywanie ksiąg kościelnych krok po kroku pokazuje, że średniowiecze w niejednym wymiarze ma przed nami jeszcze trochę niewiadomych, które czekają na odkrycie.

Jeden z pierwszych wniosków nasuwających się po przeanalizowaniu spraw diecezji poznańskiej dotyczących impotencji brzmi, że zarówno ich zakres, jak i narzędzia, jakimi posługiwali się wielkopolscy oficjałowie nie odbiegały od tych, które stosowano w nieco lepiej pod tym kątem przebadanych sądach kościelnych w zachodniej Europie $^{42}$. Wykształcenie, znajomość prawa kościelnego i umiejętności zastosowania go w praktyce oficjałów w Polsce wydają się być bardzo podobne do tych opisanych z sądów w Ely czy w Yorku (Wielka Brytania). Jest to niewielki przyczynek do potwierdzenia tezy o uniwersalnym wykształceniu wyższych urzędników kościelnych w chrześcijańskiej Europie XV w.

Z kolei statystyki pokazały, że w grupie spraw małżeńskich zgłaszanych oficjałom w diecezji poznańskiej w okresie pierwszej ćwierci $\mathrm{XV}$ w. te dotyczące impotencji stanowiły około 5 proc. Wydaje się, że problem społeczny był większy, jednak z wielu powodów nie wszystkie pary trafiały przed oblicze sędziego. W pierwszej kolejności blokadę, szczególnie we wcześniejszym okresie, powodował brak wiedzy wśród świeckich o możliwości podjęcia prób rozwiązania kłopotów na drodze sądowej. Następnie także długa i skomplikowana procedura załatwiania spraw, która zapewne zniechęcała potencjalnych kandydatów. Dużo prościej - na co wskazuje analiza materiału - było rozstać się ze współmałżonkiem i wziąć sobie innego partnera, licząc na to, że sprawa nie zainteresuje lokalnego duchowieństwa. W XV w. Kościół uznawał to za grzech i bigamię przez co aktywnie walczył z tym procederem, gdy tymczasem w praktyce społecznej było to postępowanie dość powszechne. Ta różnica myślenia była zresztą problemem w całej Europie, a wiązano ją z niejednoznaczną definicją ważności małżeństwa, a także z wynikającym $\mathrm{z}$ tego zjawiskiem określanym jako karalne w prawie kanonicznym tzw. matrimonium clandestinum, czyli związkami zawartymi w ukryciu,

z serii ksiąg konsystorskich - Depositiones testium użył Tomasz Jurek, Sprawa Marcina Zegana i Doroty Szczepankówny. Przyczynek do kwestii świadomości genealogicznej średniowiecznego chłopstwa, „Genealogia” 9, 1997, s. 91, a z kolei nadzieję na odnalezienie Montaillou, czyli wioski heretyków w polskiej przestrzeni źródłowej wyraził Jerzy Strzelczyk, Heretycy, inkwizytorzy, historycy (anatomia wioski średniowiecznej), w: Pax et bellum, red. K. Olejnik, Poznań 1993, s. 270.

${ }^{42}$ Por. przykłady omówione choćby w pracach: J.A. Brundage, Impotence, Frigidity, s. 407-423; idem, The Problem of Impotence, s. 135-140; B. Kane, op. cit., s. 7 nn., gdzie podane przykłady spraw o podejrzenie impotencji z sądów w Ely i York. 
bez zachowania właściwych procedur ${ }^{43}$. Historycy analizujący to zagadnienie podkreślają problemy ze zdefiniowaniem pojęcia „tajnego" małżeństwa. Sformułowanie to rzeczywiście zmieniało swoje znaczenie w miarę rozwijania się zagadnień związanych z kościelnym prawem małżeńskim. Początkowo określano w ten sposób związek zawarty bez zachowania wszelkich form ceremoniału, przede wszystkim bez kontroli rodziców. W kolejnych wiekach coraz częściej nazwy tej używano, by odróżnić małżeństwo zawiązane bez świadków, a przede wszystkim bez kapłana (non in facie Ecclesiae) oraz z ominięciem wcześniejszych zapowiedzi ${ }^{44}$. Zawieranie „tajnych” małżeństw było przez Kościół zabronione, jednak aż do XVI w., z uwagi na powszechność tego zjawiska, związki zainicjowane $\mathrm{w}$ ten sposób uznawane były za ważne. Innymi słowy, zawarcie małżeństwa w sposób „tajny” mogło zostać przez Kościół ukarane, jednak sama forma nie była traktowana jako przeszkoda zrywająca powstały związek ${ }^{45}$.

Analiza materiału pokazuje, iż w pierwszej połowie XV w. postępowanie oficjałów względem par oparte było na koitalnej teorii ważności małżeństwa. W praktyce oznaczało to, że małżonek, który uznał,

${ }^{43}$ M. Koczerska, Zawarcie małżeństwa wśród szlachty $w$ Polsce późnego średniowiecza, PH 66, 1975, 1, s. 5-20; M. Biniaś-Szkopek, Źródła waśni i konfliktów małżeńskich w Europie przed soborem trydenckim (wokół książki Charles'a Donahue, „Law, Marriage, and Society in the Later Middle Ages: Arguments about Marriage in Five Courts”, Cambridge 2007), „Historia Slavorum Occidentis" 15, 2017, 4, s. 101-114.

${ }^{44}$ Dyskusja na temat definicji „tajnych” małżeństw nie została dotychczas rozstrzygnięta. Donahue podkreślał, iż może być ono tłumaczone zarówno jako związek, którego zawarcia jedna ze stron nie jest w stanie udowodnić, jak i małżeństwo, którego zainicjowanie można udowodnić, choćby przez zeznania świadków, jednak nie zostało zawarte zgodnie z formułami (np. nie in facie Ecclesiae), ostatecznie oznaczać może również małżeństwo, które zawarto co prawda w kościele, jednak nie zachowano innych obowiązujących norm, np. pominięto zapowiedzi, zob. Ch. Donahue, Law, Marriage, s. 4. Por. także osobny artykuł poświęcony wyłącznie zagadnieniu „tajnych” małżeństw w średniowieczu, w którym autor podjął dyskusję na temat interpretacji sformułowania "clandestine marriage" z Andrew J. Finchem (Parental Authority and the Problem of Clandestine Marriage in the Later Middle Ages, „Law and History Review” 8, 1990, s. 189-204) Ch. Donahue, „Clandestine” Marriage in the Later Middle Ages. A Reply, „Law and History Review" 10, 1992, s. 315-322. Na ten temat także ostatnio M. Nodl, Clandestinum matrimonium, w: Memoria viva. Studia historyczne poświęcone pamięci Izabeli Skierskiej (1967-2014), red. G. Rutkowska, A. Gąsiorowski, Warszawa-Poznań 2015, s. 370-381.

${ }^{45}$ W. Abraham, Forma zawarcia zaręczyn i małżeństwa w najnowszem ustawodawstwie kościelnym, wyd. 2, Lwów 1913, s. 16; M. Żurowski, Wpływy chrześcijańskie na pierwotne prawo polskie w sprawach małżenskich, „Prawo Kanoniczne” 18, 1975, 1-2, s. 75-76; idem, Kanoniczne prawo małżeńskie Kościoła Katolickiego. Stan prawny po promulgowaniu Kodeksu Prawa Kanonicznego Kościoła Łacińskiego w 1983 r., Katowice 1987, s. 111 - autor zasugerował podział na małżeństwa „prywatne” i „tajne”, oba uznając za szkodliwe. 
że w kwestii współżycia jego partner nie wypełnia należycie swych obowiązków, mógł w majestacie prawa żądać stwierdzenia nieważności związku jako nie w pełni ratyfikowanego. Jednak w swoim postępowaniu względem par przybywających do sądu z problemem impotencji poznańscy oficjałowie nie szafowali wyrokiem divortium, czyli w praktyce stwierdzeniem nieważności małżeństwa. Tę decyzję podejmowali jako ostateczną dopiero po przeprowadzeniu wnikliwej oceny sytuacji. Jednocześnie widzimy, że choć niełatwo było ich przekonać do tego, iż niemoc płciowa jest pewna i trwała, to jednak w pełni dowiedziona impotencja była dla nich wystarczającym powodem dla uznania związku za nieważny, połączonego z daniem parze, a przynajmniej kobiecie, licencji na zawarcie innego małżeństwa. Nie znalazłam również w przebadanych księgach poznańskich żadnego wyroku, w którym obciążony impotencją małżonek otrzymałby zakaz zawarcia innego związku ${ }^{46}$.

Ostatecznie warto również podkreślić, że podejmując trud pracy nad materiałem konsystorskim, mamy niezwykłą okazję usłyszenia głosu kobiet średniowiecza i to tych pochodzących często z nizin społecznych, których w oficjalnych traktatach nie mamy szans posłuchać ${ }^{47}$. O płci pięknej, jej uczuciach, fizyczności, roli w związku, w małżeństwie, rodzinie w tej epoce pisali w przeważającej większości mężczyźni, którzy budowali jej obraz, chcąc nie chcąc, bardzo jednostronnie ${ }^{48}$. Tymczasem w sądach kościelnych to kobiety były najczęściej powódkami w zgłaszanych procesach. To one skarżyły swych mężów lub narzeczonych o niedotrzymanie danej obietnicy, zdradę i bigamię czy nadmierną przemoc. Powyżej opisane sprawy wskazują, że nie inaczej było z oskarżeniami o impotencję. W pierwszym ćwierćwieczu XV w., jak pokazuje analizowany materiał, dorosłe kobiety występowały przed sądami samodzielnie, bez konieczności wyznaczania opiekunów czy pełnomocników, co świadczy o ich wysokiej pozycji w procesie kościelnym. Materiał - szczególnie ten dotyczący małżeństw - spisany w księgach konsystorza, stanowi doskonałe źródło do analizy wielu zagadnień związanych właśnie z pozycją społeczną

${ }^{46}$ O takiej ewentualności jako pewnej praktyce pisała ostatnio choćby Małgorzata Kołacz-Chmiel, „Mulier honesta et laboriosa”. Kobieta w rodzinie chłopskiej późnośredniowiecznej Małopolski, Lublin 2018, s. 101.

${ }^{47}$ Zwracali na to uwagę choćby Jacek Wiesiołowski, Zmiany społecznej pozycji kobiety $w$ średniowiecznej Polsce, w: Kobieta $w$ kulturze średniowiecznej Europy. Prace ofiarowane Profesor Alicji Karłowskiej-Kamzowej, red. A. Gąsiorowski, Poznań 1999, s. 41-46, czy Alicja Szymczakowa, Stan badań nad rodzina szlachecka późnego średniowiecza, w: Genealogia. Stan i perspektywy badań nad społeczeństwem Polski średniowiecznej na tle porównawczym, red. J. Pakulski, J. Wroniszewski, Toruń 2003, s. 76-94.

${ }^{48}$ R. Fossier, Ludzie średniowiecza, Kraków 2009 (oryg. franc. 2007), s. 84-86. 
kobiet w średniowieczu, a także jej znaczenia w rodzinie i relacji względem męża ${ }^{49}$.

\section{Streszczenie}

W średniowieczu przez kilkaset lat toczono gorącą dyskusję na temat tego, co stanowi o ważności i nierozerwalności podstawowego dla rozwoju społeczeństw związku - małżeństwa. Polemika pomiędzy tzw. szkołami paryską i bolońską, w której głos zabierali najwięksi prawodawcy i nauczyciele tej epoki, trwała aż do soboru trydenckiego. Wcześniej prawnicy nie potrafili wypracować wspólnego stanowiska w zakresie odpowiedzi na pytanie, co tworzy w pełni ważne i zgodnie z prawem kościelnym nierozerwalne małżeństwo - consens (zgoda) czy coitus (współżycie). Wiemy, że impotencja wcześnie trafiła w poczet teoretycznych przeszkód, które mogły doprowadzić do stwierdzenia nieważności małżeństwa, jednak jak funkcjonowało to zjawisko w praktyce sądów kościelnych w różnych krajach Europy, w tym w Polsce, odpowiedzieć dużo trudniej. Dzieje się tak z powodu zbyt ubogiej podstawy źródłowej. Tymczasem księgi wytworzone przez sądy konsystorskie w średniowieczu są skarbnicą pełną wciąż niewykorzystanych materiałów źródłowych, które pomagają wzbogacić naszą wiedzę nie tylko w zakresie historii Kościoła czy funkcjonowania średniowiecznego duchowieństwa, ale także życia codziennego i obyczajowego świeckich, którzy przed oficjałem roztrząsali swoje spory małżeńskie. Autorka wybrała materiał źródłowy przechowywany w Archiwum Archidiecezjalnym w Poznaniu i po przeprowadzeniu jego szczegółowego przeglądu zestawiła sprawy par, w których żony oskarżały swych małżonków o impotencję z lat 1404-1425. Celem niniejszego tekstu było przedstawienie wyników kwerendy dotyczącej grupy 22 małżeństw średniowiecznych z terenu diecezji poznańskiej, które stanęły wobec niemożności dopełnienia związku - czyli problemu oziębłości i impotencji.

\section{The Impediments of Impotence and Frigidity in the Light of Records of the Poznan Consistory in the Fifteenth Century}

For several hundred years there was in the Middle Ages a heated debate over the question what made a marriage valid and indissoluble. A discussion between the schools of Paris and Bologna on the validity of marriage, with contribution of the most outstanding theologians and scholars, was not ended until the Council of Trent. Before that, legislators were unable to agree on the definition of what constituted valid and indissoluble marriage - was it consens (consent) or coitus (consummation). As we know, it was quite early that impotence was placed on

49 Ostatnio ciekawy przykład zob. M. Kołacz-Chmiel, op. cit., s. 99-164. 
the list of theoretical impediments of marriage that could lead to the dissolution of the matrimony. But it is much more difficult to say what was the reality of this phenomenon in the ecclesiastical courts of various European countries, including Poland. This is due to the lack of historical sources. The registers produced by medieval consistory courts, however, are a rich repository of still unused source material that make it possible to broaden our knowledge not only of the history of the Church or medieval clergy, but also of the everyday life and customs of the laity who decided to solve their marital problems before the spiritual courts. The author, on the basis of a source material from the Poznan Archdiocesan Archives, presents the actual court cases from the years 1404-25 when wives brought suit against their husbands over impotence (PAA, ref. no. AC 1-AC 8). The purpose of the present study therefore is to present an archival search of the group of 22 medieval married couples from the Poznan Diocese who were unable to consummate their marriage due to frigidity or impotence.

Translated by Grażyna Waluga

\section{Bibliografia}

Abraham Władysław, Forma zawarcia zaręczyn i małżństwa w najnowszem ustawodawstwie kościelnym, wyd. 2, nakł. Gubrynowicza i Syna, Lwów 1913.

Acta capitulorum Cracoviensis et Plocensis selecta (1438-1523, 1438-1525), wyd. Bolesław Ulanowski, Archiwum Komisji Historycznej 6 (1891), s. 1-183.

Acta capitulorum nec non iudiciorum ecclesiasticorum selecta, wyd. Bolesław Ulanowski, t. 1-3, Kraków 1894-1902-1908.

Acta Officii consistorialis Leopoliensis antiquissima, wyd. Wilhelm Rolny, Societatis Litterarum, cz. 1, Lwów 1927, cz. 2, Lwów 1930 (Zabytki Dziejowe, t. 2 i 3).

Biniaś-Szkopek Magdalena, Analiza małżńskich sporów sądowych zanotowanych w najstarszej księdze poznańskiego konsystorza, w: Stilo et animo. Prace historyczne ofiarowane prof. Tomaszowi Jasińskiemu w 65. rocznicę urodzin, red. Maciej Dorna, Marzena Matla, Miłosz Sosnowski, Ewa Syska, Instytut Historii UAM, Poznań 2016, s. 257-270.

Biniaś-Szkopek Magdalena, Funkcjonowanie sądu konsystorskiego w Poznaniu w pierwszych latach XV wieku, w: Sacrum w mieście, t. 1: Średniowiecze i wczesna epoka nowożytna. Wymiar religijny, kulturalny i społeczny, red. Danuta Quirini-Popławska, Łukasz Burkiewicz, Akademia Ignatianum, Wydawnictwo WAM, Kraków 2016, s. 189-200.

Biniaś-Szkopek Magdalena, Kobiety, mężczyźni i małżenstwo w najstarszych księgach konsystorskich poznańskich, w: Kobieta i mężczyzna. Jedna przestrzeń - dwa światy, red. Bożena Popiołek, Agnieszka Chłosta-Sikorska, Marcin Gadocha, DiG, Kraków 2015, s. 27-36.

Biniaś-Szkopek Magdalena, Źródła waśni i konfliktów małżeńskich w Europie przed soborem trydenckim (wokół książki Charles'a Donahue, „Law, Marriage, and Society in the Later Middle Ages: Arguments about Marriage in Five Courts", Cambridge 2007), „Historia Slavorum Occidentis” 15, 2017, 4, s. 101-114. 
Biskupski Stefan, Prawo małżeńskie Kościoła rzymskokatolickiego, t. 1, Warszawa 1956 (wyd. 1).

Biskupski Stefan, Prawo małżeńskie Kościoła rzymskokatolickiego, t. 1: Teoria małżeństwa i prawo materialne, przyg. i uzup. zgodnie z prawem posoborowym Marian Żurowski, Warszawa 1971 (wyd. 2).

Brundage James A., Concubinage and Marriage in Medieval Canon Law, „Journal of Medieval History" 1, 1975, 1, s. 1-17.

Brundage James A., Impotence, Frigidity and Marital Nullity in the Decretists and the Early Decretalists, w: idem, Sex, Law and Marriage in the Middle Ages, Variorum, Aldershot-Brookfield 1993, s. 407-423.

Brundage James A., Law, Sex and Christian Society in Medieval Europe, University of Chicago Press, Chicago 1990.

Brundage James A., The Problem of Impotence, w: Sexual Practices and the Medieval Church, red. Vern L. Bullough, James Brundage, Prometheus Books, Buffalo 1982, s. 135-140.

Corpus iuris canonici, edidtio Lipsiensis secunda, wyd. Aemilius Ludovicus Richter, instruxit Aemilius Friedberg, pars secunda, Lipsiae 1881 [Graz 1959].

Cracovia artificum 1300-1500, wyd. Jan Ptaśnik, Kraków 1917 (Źródła do Historii Sztuki i Cywilizacji w Polsce, t. 4).

Cracovia artificum 1501-1550, zebrał Jan Ptaśnik, do druku przyg. Marian Friedberg, Kraków 1936, 1948 (Źródła do Historii Sztuki i Cywilizacji w Polsce, t. 4, 5, z. 1-2).

Cracovia impressorum XV et XVI saeculorum, wyd. Jan Ptaśnik, Ossolineum, Lwów 1922 (Monumenta Poloniae Typographica, t. 1).

d'Avray David L., Medieval Marriage. Symbolism and Society, Oxford University Press, Oxford 2005.

Delimata Małgorzata, „[...] ipsam idem dux tenerrime et omni affectu diligebat”, czyli o więziach małżeńskich w polskim średniowieczu (wybrane przykłady), w: Gospodarka, społeczeństwo, kultura w dziejach nowożytnych. Studia ofiarowane Pani Profesor Marii Boguckiej, red. Andrzej Karpiński, Edward Opaliński, Tomasz Wiślicz, DiG, Warszawa 2010, s. 91-101.

Delimata Małgorzata, „Mulieres suspectae” - przypadki niewiernych żon w aktach sąów kościelnych, „Acta Universitatis Wratislaviensis” 177, 2008, s. 287-292.

Delimata Małgorzata, Wiarołomni mężowie przed polskimi sądami kościelnymi, „Nasza Przeszłość" 104, 2005, s. 247-258.

Dokumenty soborów powszechnych. Tekst łaciński, polski, t. IV/1, IV/2: (1511-1870), Lateran V, Trydent, Watykan I, układ i oprac. Arkadiusz Baron, Henryk Pietras, Wydawnictwo WAM - Księża Jezuici, Kraków 2007.

Donahue Charles, „Clandestine” Marriage in the Later Middle Ages. A Reply, „Law and History Review" 10, 1992, s. 315-322.

Donahue Charles, Law, Marriage, and Society in the Later Middle Ages. Arguments about Marriage in Five Courts, Cambridge University Press, Cambridge 2007.

Duby Georges, Rycerz, kobieta i ksiądz. Małżenstwo w feudalnej Francji, Warszawa 1986 (oryg. franc. 1981).

Finch Andrew J., Parental Authority and the Problem of Clandestine Marriage in the Later Middle Ages, „Law and History Review” 8, 1990, s. 189-204. 
Fossier Robert, Ludzie średniowiecza, Wydawnictwo WAM, Kraków 2009.

Handbook of Medieval Sexuality, red. Vern L. Bullough, James A. Brundage, Garland, New York 1996.

Hemperek Piotr, Sprawy małżeńskie w oficjalacie okręgowym w Lublinie w XV w., „Roczniki Teologiczno-Kanoniczne" 17, 1970, 5, s. 27-44.

Hemperek Piotr, Góralski Wojciech, Historia źródeł i nauki prawa kanonicznego, Redakcja Wydawnictw KUL, Lublin 1995 (Komentarz do kodeksu prawa kanonicznego z 1983 r., t. 1, cz. 1).

Hugonis de S. Victore, De B. Mariae virginitate, w: Patrologia Latina, t. 176, ed. nova, wyd. J.P. Migne, Parisiis 1880, szp. 858-876.

Jurek Tomasz, Sprawa Marcina Zegana i Doroty Szczepankówny. Przyczynek do kwestii świadomości genealogicznej średniowiecznego chłopstwa, „Genealogia” 9, 1997, s. 83-97.

Kane Bronach, Impotence and Virginity in the Late Medieval Ecclesiastical Court of York, Borthwick Texts, York 2008 (Borthwick Paper 114).

Karras Ruth Mazo, Seksualność w średniowiecznej Europie, PIW, Warszawa 2012.

Karras Ruth Mazo, Unmarriages. Women, Men, and Sexual Unions in the Middle Ages, University of Pennsylvania Press, Philadelphia 2012.

Koczerska Maria, Zawarcie małżenstwa wśród szlachty $w$ Polsce późnego średniowiecza, PH 66, 1975, 1, s. 5-20.

Kołacz-Chmiel Małgorzata, „Mulier honesta et laboriosa”. Kobieta w rodzinie chłopskiej późnośredniowiecznej Małopolski, Wydawnictwo UMCS, Lublin 2018.

Kozak Adam, Łukaszewski Jakub, Osieczna i jej mieszkańcy w świetle najstarszych ksiag konsystorza poznańskiego (1404-1425), „Rocznik Leszczyński” 15, 2015, s. 53-67.

Kozak Adam, Miejsca działalności konsystorza generalnego w Poznaniu i jego pisarzy w pierwszej ćwierci XV wieku, w: Loca scribendi. Miejsca i środowiska tworzace kulture pisma w dawnej Rzeczypospolitej XV-XVIII stulecia, red. Anna Adamska, Agnieszka Bartoszewicz, Maciej Ptaszyński, Wydawnictwa UW, Warszawa 2017, s. 126-151.

Krawiec Adam, Pożądanie i rytuał. Seksualność małżeńska w późnym średniowieczu, w: Manželství v pozdním středověku. Rituály a obyčeje, red. Paweł Kras, Martin Nodl, Filosofia, Praha 2014 (Colloquia mediaevalia Pragensia 14), s. 237-248.

Krawiec Adam, Seksualność w średniowiecznej Polsce, Wydawnictwo Poznańskie, Poznań 2000.

Książkiewicz Aleksandra, Sprawy małżeńskie w konsystorzu lwowskim w późnym średniowieczu, „Nasza Przeszłość” 109, 2008, s. 287-302.

Laudum Vartense, wyd. Bolesław Ulanowski, RWHF PAU 21, Kraków 1887.

Le Roy Ladurie Emmanuel, Montaillou. Wioska heretyków 1294-1324, przedm. Ewa Domańska, Czerwonak 2014.

Makowski Elizabeth M., The Conjugal Debt and Medieval Canon Law, „Journal of Medieval History" 3, 1977, s. 99-114.

Mathon Gérard, Le mariage des chrétiens, t. 1: Des origins au concile de Trente, Paris 1993.

Michalski Maciej, Coitus albo consensus, czyli co stanowi o ważności małżeństwa. Relacja z pewnej dyskusji z XI-XIII wieku, w: Nihil superfluum esse. Studia z dziejów średniowiecza ofiarowane Profesor Jadwidze Krzyżaniakowej, red. Jerzy Strzelczyk, Józef Dobosz, Instytut Historii UAM, Poznań 2000, s. 159-166. 
Nodl Martin, Clandestinum matrimonium, w: Memoria viva. Studia historyczne poświęcone pamięci Izabeli Skierskiej (1967-2014), red. Grażyna Rutkowska, Antoni Gąsiorowski, Instytut Historii PAN, Warszawa-Poznań 2015, s. 370-381.

Noonan John T., Marital Affection in the Canonists, „Studia Gratiana” 12, 1967, s. 479509.

O pokucie publicznej w Polsce, wyd. Bolesław Ulanowski, RWHF PAU 23, Kraków 1888. Ozorowski Mieczysław, Zarys historyczny teologii małżeństwa w średniowieczu, „Studia Teologiczne. Białystok - Drohiczyn - Łomża" 14, 1996, s. 269-277.

Magistri Petri Lombardi Parisiensis episcopi Sententiae in IV libris distinctae, Spicilegium Bonaventurianum 4-5, Editiones Collegii S. Bonaventurae ad Claras Aquas, Grottaferrata 1971-1981.

Praktyka w sprawach małzeńskich w sądach duchownych diecezji krakowskiej, wyd. Bolesław Ulanowski, „Archiwum Komisji Historycznej” 5, 1889.

Regesta pontificum romanorum ab condita Ecclesia ad annum post Christum natum MCXCVIII, t. 2, wyd. Philipp Jaffé, Gulielmi Wattenbach [et al.], Lipsiae 1888.

Reynolds Philip L., How Marriage Became One of the Sacraments. The Sacramental Theology of Marriage from its Medieval Origins to the Council of Trent, Cambridge University Press, Cambridge 2016.

Skierska Izabela, Rozwiązanie małżeństwa w Polsce późnego średniowiecza w świetle praktyki sądów kościelnych, w: Manželství v pozdním středověku. Rituály a obyčeje, red. Paweł Kras, Martin Nodl, Filosofia, Praha 2014 (Colloquia mediaevalia Pragensia 14), s. 25-52.

Skierska Izabela, Źródła do badania praktyk religijnych w średniowiecznej Polsce. Akta sądów kościelnych i kapitut, „Archiwa, Biblioteki i Muzea Kościelne” 87, 2007, s. $175-195$.

Stomma Ludwik, Rytuał pokładzin w Polsce. Analiza strukturalna, „Etnografia Polska” 19, 1975, 1, s. 51-64.

Strzelczyk Jerzy, Heretycy, inkwizytorzy, historycy (anatomia wioski średniowiecznej), w: Pax et bellum, red. Karol Olejnik, Wydawnictwo Naukowe UAM, Poznań 1993, s. 259-270.

Szymczakowa Alicja, Obrazki z życia małżeńskiego (i nie tylko) w Polsce centralnej $w$ średniowieczu, w: Rycerze, wędrowcy, kacerze. Studia z historii średniowiecznej i wczesnonowożytnej Europy Środkowej, red. Beata Wojciechowska, Waldemar Kowalski, Wydawnictwo Uniwersytetu Jana Kochanowskiego, Kielce 2013, s. 347-355.

Szymczakowa Alicja, Stan badań nad rodziną szlachecką późnego średniowiecza, w: Genealogia. Stan i perspektywy badań nad społeczeństwem Polski średniowiecznej na tle porównawczym, red. Jan Pakulski, Jan Wroniszewski, Wydawnictwo Uniwersytetu Mikołaja Kopernika, Toruń 2003, s. 76-94.

Teksty źródłowe do dziejów kultury i sztuki z archiwaliów kurialnych i kapitulnych w Krakowie 1433-1440, wybrał i oprac. Bolesław Przybyszewski, Ossolineum, PAN, Wrocław 1988 (Cracovia artificum. Supplementa, 2).

Teksty źródłowe do dziejów kultury i sztuki z najdawniejszych oficjaliów krakowskich 14101412 oraz 1421-1424, wybrał i oprac. Bolesław Przybyszewski, Ossolineum, PAN, Wrocław 1985 (Cracovia artificum. Supplementa, 1).

Tunia Anna, Kształtowanie się kanonicznej formy zawarcia małżeństwa, „Roczniki Nauk Prawnych" 1, 2008, 18, s. 129-159. 
Ulanowski Bolesław, o pracach przygotowawczych do historyi prawa kanonicznego w Polsce, Gebethner i Sp., Kraków 1887.

Wiesiołowski Jacek, Zmiany społecznej pozycji kobiety w średniowiecznej Polsce, w: Kobieta w kulturze średniowiecznej Europy. Prace ofiarowane Profesor Alicji Karłowskiej-Kamzowej, red. Antoni Gąsiorowski, Wydawnictwo PTPN, Poznań 1999, s. $41-46$.

Zawilski Marcin, Małżeństwo, kobieta, cielesność. Instytucja małżeństwa w XII- i XIII-wiecznej Francji, Historia Iagellonica, Kraków 2008.

Zubert Bronisław W., Przeszkoda wieku do małżeństwa $w$ dekretałach papieskich i nauce prawa w drugiej połowie XII wieku, „Prawo Kanoniczne” 13, 1970, 3-4, s. 71-126.

Żurowski Marian, Kanoniczne prawo małżńskie Kościoła Katolickiego. Stan prawny po promulgowaniu Kodeksu Prawa Kanonicznego Kościoła Łacińskiego w 1983 r., Księgarnia św. Jacka, Katowice 1987.

Żurowski Marian, Wpływy chrześcijańskie na pierwotne prawo polskie w sprawach matżeńskich, „Prawo Kanoniczne” 18, 1975, 1-2, s. 73-87.

Biogram: dr Magdalena Biniaś-Szkopek, adiunkt w Zakładzie Archiwistyki Instytutu Historii Uniwersytetu im. Adama Mickiewicza w Poznaniu, zawodowo związana jest również z Biblioteką Kórnicką Polskiej Akademii Nauk. Doktorat ukończyła w 2007 r., broniąc pracy pt. „Bolesław IV Kędzierzawy - książę Mazowsza i princeps", napisanej pod kierunkiem naukowym Józefa Dobosza. Zainteresowania badawcze: historia Polski okresu rozbicia dzielnicowego, dzieje kancelarii kościelnych oraz prawa małżeńskiego w średniowieczu, w tym konfliktów małżeńskich w Polsce w średniowieczu; kontakt: biszkopt@amu.edu.pl. 